\title{
Introgression of anthracnose resistance Co-4 gene in elite French bean (Phaseolus vulgaris L.) background using linked molecular marker SY20
}

Bansuli . ( $\sim$ bansuli777@gmail.com )

CSK HPKV: Himachal Pradesh Agricultural University

\section{Research Article}

Keywords: French bean, Anthracnose, Collectrotrichum lindemuthianum, Co-4, SY20

Posted Date: February 8th, 2022

DOI: https://doi.org/10.21203/rs.3.rs-1299085/v1

License: (9) This work is licensed under a Creative Commons Attribution 4.0 International License. Read Full License 


\section{Abstract}

French bean is one of the most important staple foods in many parts of the world. Among several bacterial, fungal and viral diseases, anthracnose caused by Colletotrichum lindemuthianum is the most widespread and severe disease of French bean. Therefore, the present study was undertaken with the objective of introgression of important bean anthracnose resistance gene Co-4 in elite cultivar. Hybridisation between resistant genotype, TO having bean anthracnose resistance gene Co-4 and elite cultivar Arka Komal was done. Cross Arka Komal $\times \mathrm{TO}$ was further advanced to generate $\mathrm{F}_{1}, \mathrm{BC}_{1} \mathrm{~F}_{1}, \mathrm{BC}_{2} \mathrm{~F}_{1}$ and $\mathrm{BC}_{2} \mathrm{~F}_{2}$ plants. Testing of hybridity of the resultant $F_{1}, B C_{1} F_{1}, B C_{2} F_{1}$ and $B C_{2} F_{2}$ plants/pods using gene linked SCAR marker SY2O resulted in identification of 46 genepositive $\mathrm{BC}_{2} \mathrm{~F}_{2}$. Further foreground selection revealed lack of segregation for the target gene Co-4 in 16 progenies. Screening of progenies following detached pod and germinated seed dip methods using race 3 of $C$. lindemuthianum validated Co-4 imparted resistance in all the $16 \mathrm{BC}_{2} \mathrm{~F}_{3}$ progenies. Agronomic evaluation of $16 \mathrm{Co}-4$ gene-positive $\mathrm{BC}_{2} \mathrm{~F}_{4}$ progenies for 8 qualitative traits and 9 quantitative traits identified AKTO 4, AKTO 5, AKTO 7 and AKTO 43 progenies as having better elite background. These can either be used as donors of resistance gene for further introgression and gene pyramiding or can further be advanced following backcrossing to develop essentially derived variety of elite parent, Arka Komal.

\section{Introduction}

French bean belongs to order Fabales and family Fabaceae, sub family Papilionideae, tribe Phaseoleae, sub-tribe Phaseolionae and genus Phaseolus. French bean is an autogamous diploid $(2 n=2 x=22)$ species with a comparatively small genome $\otimes 587 \mathrm{mbp}$ (Bennett and Leitch 1995; Broughton et al. 2003) and genetic consensus map is structured into 11 chromosomes (Nodari et al. 1993; Freyre et al. 1998; Pedrosa-Harand et al. 2008). Beans comprises of two major eco-geographical gene pools, Middle America and the Andes (Kwak and Gepts 2009). French bean is a rich and low-cost source of protein, fiber and other important minerals, i.e. iron, zinc, copper, phosphorus, potassium, magnesium, calcium and many vitamins (Limongelli et al. 1996; Kaur et al. 2009; Khetan et al. 2015). Therefore, the crop is considered an economically, nutritionally and socially important (Broughton et al. 2003; Pujola et al. 2007; Mishra et al. 2010; Singh et al. 2012). Green beans are cultivated throughout the world over an area of about 1.56 million hectares with a production and productivity of 23.60 million tonnes and 15.15 tonnes/ha, respectively $(F A O, 2016)$. Latin America is the largest producer with Brazil and Mexico being by far the major producers. Africa is the second most important region, producing about 2.5 million metric tons, with Uganda, Kenya, Rwanda, Burundi, Tanzania and Congo playing major roles (CGIAR French bean, 2012). In India, green beans are cultivated over an area of 241 thousand hectares with a production and productivity of about 675 thousand tonnes and 2.80 tonnes/ha, respectively (FAO, 2017).

Several bacterial, fungal and viral diseases attack French bean and among these anthracnose caused by fungus Colletotrichum lindemuthianum is one of the most widespread and severe. This disease can cause yield losses of up to $100 \%$ when infected seed is sown in areas with high relative humidity and mild temperatures range from 18 to $24{ }^{\circ} \mathrm{C}$ (Peloso 1992). Majority of the recommended and locally adapted bean cultivars in Himachal Pradesh are susceptible to different races of pathogen (Sharma et al. 1999). The most prevalent races in the region are race $3,115,513,515,529,537,615,631,775$ and 935 (Pathania et al. 2006). Studies on race spectrum of bean anthracnose have revealed presence of 27 races in all from North Western Himalayan region, out of which 19 are reported to be present in Himachal Pradesh (Sharma et al. 2019) Both cultural management and use of fungicides can be followed to control the disease. However, chemical control is found to be expensive and generation of pathogen free seeds is often difficult in developing countries. So, the use of resistant genotypes emerges to be the most biologically safe and cost-effective management strategy (Pastor-Corrales and Tu 1989). A large number of studies on genetics of resistance to anthracnose have revealed it to be governed by 26 anthracnose resistance loci identified and denoted by the symbol Co including Co-1 to Co-7, co-8, Co-9 to Co-18, Co-u to Co-z (Kelly and Vallejo 2004; Goncalves-Vidigal et al. 2012), CoPvO9 (Campa et al. 2014) and Co-Pa (de Lima Castro et al. 2017). Many improved pencil type varieties developed by public and private sectors are available for cultivation by the farmers of the state however most of these are susceptible to many prevalent races of bean anthracnose. Arka Komal is such preferred bush type French bean variety grown by the farmers of Himachal Pradesh and its adjoining hilly and plain areas which are highly susceptible to this disease. Thus there is need to develop French bean variety having resistance to bean anthracnose to counter threats of this disease on bean production. Therefore, the present study is proposed with the objectives of introgression of important bean anthracnose resistance gene $\mathrm{Co}-4$ in elite cultivar and to assess the derivatives for validation of imparted resistance. The study will result in identification of anthracnose resistant derivatives which can further be advanced to isolate derived variety (ies) and used as prebreeding material in bean anthracnose breeding programme. 


\section{Materials And Methods}

\section{Plant material}

The French bean genotype TO (Co-4) was used as resistance donor against bean anthracnose, whereas French bean Arka Komal was used as recipient parent.

\section{Hybridisation and backcrossing to generate $\mathrm{F}_{1}, \mathrm{BC}_{1} \mathrm{~F}_{1}$ and $\mathrm{BC}_{2} \mathrm{~F}_{1}$ seeds}

The hybridization was attempted between bean anthracnose resistance gene donor genotype TO and elite cultivar Arka Komal gene donor as male parent. The $F_{1}$ progenies (Arka Komal $\times$ TO) were then backcrossed with respective elite parent using $F_{1}$ as male parent. The process of hybridization involved emasculation of the flowers and artificial pollination of emasculated flowers next morning.

The data on total number of flowers emasculated and pollinated and total number of pods set were collected cross-wise. Crossability was expressed as the per cent pod set in hand pollinated flowers and was calculated as follows:

Crossability $(\%)=($ Total number of pods set $/$ Total number of flowers pollinated $) \times 100$

\section{Marker assisted foreground selection}

The DNA for marker analysis was extracted by CTAB method (Murray and Thompson, 1980). The SCAR marker SY20 reported to be linked to the targeted bean anthracnose resistance gene $\mathrm{Co}_{\mathrm{A}} 4$ was used to identify the plants carrying the resistance gene in $\mathrm{F}_{1}$, $\mathrm{BC}_{1} \mathrm{~F}_{1}, \mathrm{BC}_{2} \mathrm{~F}_{1}, \mathrm{BC}_{2} \mathrm{~F}_{2}$ and $\mathrm{BC}_{2} \mathrm{~F}_{3}$ progenies.

\section{Isolation, purification and quantification of the plant genomic DNA}

Genomic DNA of plants of parents and various generations were isolated from young leaves using CTAB method (Murray and Thompson 1980). The extracted DNA samples were loaded on $1 \%$ agarose gel (1gm/100ml $1 \mathrm{X}$ TAE Buffer) and run at $90 \mathrm{~V}$ for 30 mins to ascertain the quality and quantity of DNA.

\section{PCR amplification}

DNA samples were used for PCR amplification by using SY20 SCAR primer (F: AGCCGTGGAAGGTTGTCAT, Tm - 56.9 ${ }^{\circ}$; R: CCGTGGAAACAACACACAAT, Tm $-53.9^{\circ} \mathrm{C}$ ). For amplification of genomic DNA, a reaction mixture was prepared using PCR water, DNA (15-25 ng/ $\mu \mathrm{l}), 10 \mathrm{X}$ buffer $(10 \mathrm{mM})$, dNTP mix (0.5 mM each of dATP, dGTP, dCTP, dTTP), forward primer (5 pM), reverse primer $(5 \mathrm{pM})$ and Taq polymerase $(3 \mathrm{U} / \mu \mathrm{l})$. The amplification was carried out in Veriti 96 wells Thermal Cycler (Applied Biosystem, CA, USA) following PCR amplification profile for Co-4. The PCR cycle for SY20 scar marker consisted of 2 min at $94^{\circ} \mathrm{C}$; followed by 30 cycles of $30 \mathrm{~s}$ at $94^{\circ} \mathrm{C}, 1 \mathrm{~min}$ at $59.2^{\circ} \mathrm{C}$ and $1.5 \mathrm{~min}$ at $72^{\circ} \mathrm{C}$; a $5 \mathrm{~min}$ extension at $72^{\circ} \mathrm{C}$; and a hold at $4^{\circ} \mathrm{C}$.

\section{Analysis of PCR products}

For analysis of PCR products, $2 \%$ agarose gel was prepared in 1 X Tris-Acetate-EDTA and ethidium bromide $(0.5 \mu \mathrm{g} / \mathrm{ml})$ was added to gel solution before setting the gel on casting plate. The PCR products $(10 \mu \mathrm{l})$ along with $2 \mu \mathrm{l}$ loading dye $(0.25 \%$ bromophenol blue and $40 \%$ sucrose) were loaded in the gel inside the electrophoresis tank along with a 100 bp DNA ladder and resolved on $2 \%$ agarose gel. Electrophoresis was carried out at 100-120 V for 90 mins and finally the gel was visualised and photographed using the Gel-Documentation Unit (Labnet, ENDURO ${ }^{\text {TM }}$ GDS, Aplegen). Presence/absence of appropriate size product of the marker $S Y 20$ (830 bp) linked to the anthracnose resistant gene, $\mathrm{Co}-4$ was recorded to infer the presence of $\mathrm{Co}-4$ gene in the parents and progenies.

\section{Validation of anthracnose resistance}

Cultures of $C$. lindemuthianum race-3 showing virulence on susceptible parent and avirulence on $C o-4$ gene harbouring resistant parent To, were used for screening and validation of Co-4 imparted anthracnose resistance in homozygous selected lines harbouring resistance genes. Validation of resistance was done following detached pod and germinated seed dip method. 
Screening by detached pod method was repeated twice to confirm the disease reactions. Infection type on inoculated pods was evaluated for disease severity by following the rating scale of 0-9 (Mayee and Dattar 1986) as given below, where

$0=$ No disease on pods

$1=$ Minute flecks on pods

$3=$ Brown sunken spots, $<1$ per cent pod area

$5=$ Brown spots, 1-10 per cent pod area

7= Circular brown sunken spots, 11-25 per cent pod area

$9=$ Circular to irregular, $>26$ per cent pod area

Pods scoring reaction types of 0,1 and 3 were graded as resistant while those scoring 5, 7 and 9 were graded as susceptible.

In seed dip method the reactions of inoculated seedlings were scored after six and twelve days of inoculation following $0-5$ scale (Drijfhout and Davis 1989), where

$0=$ No disease

$1=$ Pin point lesions

$2=$ Small lesions, not sunken

$3=$ large sunken lesions

4 = large, deep lesions up to stem centre

$5=$ seedling killed by the pathogen

Plants scoring reaction types of 0,1 and 2 were graded as resistant while those scoring 3,4 and5 were graded as susceptible.

Agronomic evaluation of selected Co-4 gene-positive anthracnose resistant homozygous derivatives

\section{Experimental site, material and layout design}

The agronomic evaluation of 16 selected Co-4 gene-positive homozygous $\mathrm{BC}_{2} \mathrm{~F}_{4}$ derivatives exhibiting anthracnose resistance was conducted under protected cultivation facilities (cage-house). The site is situated at an elevation of 1,290.8 $\mathrm{m}$ above mean sea level with $32^{\circ} 6^{\prime} \mathrm{N}$ latitude and $76^{\circ} 3^{\prime} \mathrm{E}$ longitude. Seeds of 16 selected $\mathrm{Co}-4$ gene-positive homozygous derivatives $\left(\mathrm{BC}_{2} \mathrm{~F}_{4}\right.$ seeds) along with both parents i.e. Arka Komal and TO were planted for evaluating the agronomic and horticultural traits. Parents along with gene-positive homozygous derivative lines were planted in a replicated trial following Completely Randomized Block Design (CRBD) in single rows of $1.25 \mathrm{~m}$ each replicated thrice. Recommended cultural practices were followed to raise the crop.

\section{Data recording}

Data were recorded on randomly selected 5 plants in each line/progeny and replication on the following 8 qualitative and 9 quantitative important agro-horticultural traits each as per the details given below:

\section{Qualitative traits}

\section{Growth habit of plant}

The growth habit of the plants was characterized as trailing, intermediate trailing, bush type and segregating recorded on each progeny/line.

\section{Pod shape}

Page $4 / 27$ 
The shape of pods of all plants of each line was observed visually and categorized on majority basis as curved, moderately curved, slightly curved and straight.

\section{Pod colour at picking stage}

The pod colour at picking stage was observed visually and categorized on majority basis as green.

\section{Stem colour}

The stem colour was observed visually and categorized on majority basis as green.

\section{Seed coat pattern}

The seed coat pattern of the seeds was characterized as mottled and absent on each homozygous progeny/line.

\section{Seed coat colour}

The seed coat colour of the seeds was observed visually and categorized as different ranges from greyish white to brown, greyish white to dark brown, greyish white to light brown, greyish white to beige, greyish white to light beige, greyish white to golden brown, greyish white to pinkish brown and greyish white.

\section{Presence of colour on around of hilum}

The presence and absence of colour on around of hilum was observed visually on each homozygous derivative line along with parents.

\section{Brilliance of seeds}

The brilliance of seeds was characterized as medium and shiny on each homozygous progeny/line along with parents.

\section{Quantitative traits}

\section{Days to flowering initiation}

Days from date of sowing to the day when first flower appeared on the plants of line were recorded for each line in each replication.

\section{Days to 50 per cent flowering}

Days from date of sowing to the day when almost all plants had 50 per cent flowering were recorded for each line in each replication.

\section{Plant height at 50 per cent flowering (cm)}

Height of 5 randomly selected plants of each line was measured at 50 per cent flowering stage from ground to tip of plant and the mean recorded as plant height in $\mathrm{cm}$ for each row in each replication.

\section{No. of branches/plant}

Branches present on each 5 individual randomly selected plants were counted and mean recorded for each line in each replication.

\section{No. of pod bearing nodes/plant}

Number of pod bearing nodes was counted on all 5 individual selected plants and average recorded for each line in all replications.

\section{Pods/node}

Pods present on all pod bearing nodes of the selected 5 plants in each line were counted and average recorded for each line in all replications. 


\section{Pods/plant}

Total green tender pods picked from selected 5 plants under different pickings were counted and mean recorded for each line in all replications.

\section{Pod length (cm)}

Length of the ten randomly chosen green pods picked from 5 selected plants was measured and average recorded in $\mathrm{cm}$ for each line in all replications.

\section{Green pod yield/plant (g)}

The green pod yield obtained from the 5 randomly selected plants under different pickings was summed and average recorded in grams (g) for each line in all replications.

\section{Statistical analysis}

The data collected on 9 quantitative traits were subjected to analysis of variance (ANOVA) following standard statistical procedure following Panse and Sukhatme (1984) as per the model and ANOVA given below:

$Y_{i j} \quad=\quad \mu+g_{i}+r_{j}+e_{i j}$

where,

$\mathrm{Y}_{\mathrm{ij}} \quad=\quad$ Phenotypic observation of the ith entry in the jth replicate,

$\begin{array}{lll}\mu & = & \text { General mean, } \\ g_{i} & = & \text { Effect of ith entry, } \\ r_{j} & = & \text { Effect of jth replication, and } \\ e_{i j} & = & \text { Error component. }\end{array}$

\section{Analysis of variance}

\begin{tabular}{|llll|}
\hline Source & Df & Mean squares & Expected mean squares \\
\hline Replication & $(\mathrm{r}-1)$ & $\mathrm{M}_{\mathrm{r}}$ & $\sigma_{\mathrm{e}}{ }^{2}+\mathrm{g} \sigma_{\mathrm{r}}{ }^{2}$ \\
\hline Entries & $(\mathrm{g}-1)$ & $\mathrm{M}_{\mathrm{g}}$ & $\sigma_{\mathrm{e}}{ }^{2}+\mathrm{r}_{\mathrm{g}}{ }^{2}$ \\
\hline Error & $(\mathrm{r}-1)(\mathrm{g}-1)$ & $\mathrm{M}_{\mathrm{e}}$ & $\sigma_{\mathrm{e}}{ }^{2}$ \\
\hline
\end{tabular}

where,

$\begin{array}{lll}r & = & \text { Number of replications, } \\ \mathrm{g} & = & \text { Number of entries/genotypes, } \\ \sigma_{\mathrm{e}}^{2} & = & \text { Error variance, } \\ \sigma_{\mathrm{r}}^{2} & = & \text { Variance due to replications and } \\ \sigma_{\mathrm{g}}{ }^{2} & = & \text { Variance due to entries. }\end{array}$

The entries/genotypes mean sum of squares were tested against error mean squares by " $F$ " test at $(\mathrm{g}-1)$ and $(\mathrm{r}-1) \times(\mathrm{g}-1)$ degree of freedom at $\mathrm{P} \leq 0.05$ for statistical significance of differences among genotypes/entries. Based on the above ANOVA, the following 
statistical parameters were calculated for inference of the data and its interpretations:

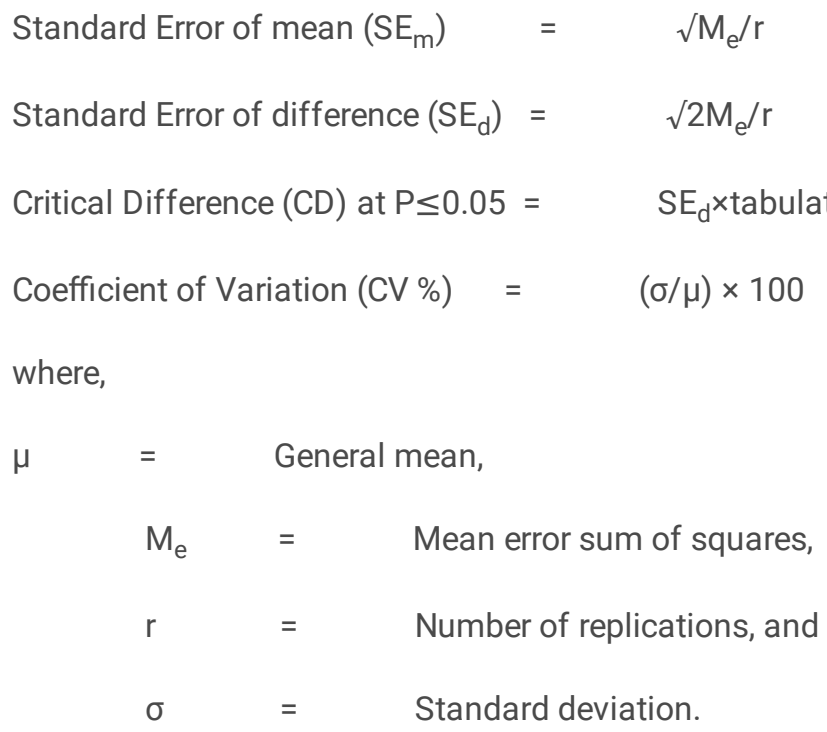

\section{Results}

\section{Hybridisation and backcrossing to generate $\mathrm{F}_{1}, \mathrm{BC}_{1} \mathrm{~F}_{1}$ and $\mathrm{BC}_{2} \mathrm{~F}_{1}$ seeds}

Bean anthracnose resistant genotype, TO known to harbour bean anthracnose resistance gene, Co- 4 was crossed with elite cultivar, Arka Komal known to be susceptible to the disease. Resistant genotype was used as male parent to generate $F_{1}$ seeds. For the cross Arka Komal $\times$ TO, 104 flowers were emasculated and pollinated. Out of these only eleven pollinations were successful leading to development of 11 ( 8 were validated by marker) revealing thereby a crossability rate of $7.69 \%$ under Palampur cage house conditions.

\section{Validation of hybridity of developed $\mathrm{F}_{1}$ seeds}

At the young stage, hybridity of 11 pod progenies of cross Arka Komal × TO was validated using Co-4 linked SCAR marker, SY2O. The results obtained are presented in Fig. 1. Out of 11 representative plants of each developed pod only eight exhibited presence of desirable amplicon (830 bp) of molecular marker, SY20 linked to the gene Co-4 indicating the hybrid nature, whereas amplification of marker failed in case of three plants i.e. plant number 3,9 and 10. The likelihood of such pods developing as a result of selfing can be due to misjudgement in identifying appropriate stage flowers and/ a result of leftover anthers in the emasculated flowers.

Selected gene-positive $8 \mathrm{~F}_{1}$ plants of cross Arka Komal $\times$ TO were used for backcrossing with elite parent. Overall 68 flowers of Arka Komal were emasculated and pollinated with pollens of the 8 hybrid plants to develop $B_{1} F_{1}$ progenies during the season resulting in development of 3 putative $\mathrm{BC}_{1} \mathrm{~F}_{1}$ pods. The foreground selection using SY20 for Cross \{Arka Komal $\times \mathrm{F}_{1}$ (Arka Komal $\times$ TO)\} indicated that out of 3 putative $\mathrm{BC}_{1} \mathrm{~F}_{1}$ plants, representative plants of all three pods exhibited desired amplicon of $830 \mathrm{bp}$ and were thus inferred to be gene-positive and true $B_{1} F_{1}$ ( Fig. 2). Selected 3 gene-positive $B_{1} F_{1}$ plants were used for further backcrossing with the elite parent, Arka Komal. To develop $\mathrm{BC}_{2} \mathrm{~F}_{1}$ progenies 96 flowers of Arka Komal were emasculated and pollinated with pollen of the 3 selected gene-positive $\mathrm{BC}_{1} \mathrm{~F}_{1}$ plants during the season - III resulting in development of $6 \mathrm{BC}_{2} \mathrm{~F}_{1}$ pods. The foreground selection using SY2O for cross [Arka Komal $\times \mathrm{BC}_{1} \mathrm{~F}_{1}\left\{\right.$ Arka Komal $\times \mathrm{F}_{1}$ (Arka Komal $\times \mathrm{TO}$ ) \}] indicated that out of 6 putative $\mathrm{BC}_{2} \mathrm{~F}_{1}$ plants, only two plants exhibited desired amplicon of $830 \mathrm{bp}$ and were thus inferred to be gene-positive and true $\mathrm{BC}_{2} \mathrm{~F}_{1}(\mathrm{Fig}$.

3). The remaining 4 pods were inferred to be self and hence not advanced further.

\section{Selfing of $\mathrm{BC}_{2} \mathrm{~F}_{1}$ plants to develop $\mathrm{BC}_{2} \mathrm{~F}_{2}$ seeds and selection of gene-positive $\mathrm{BC}_{2} \mathrm{~F}_{2}$ plants}

After molecular validation of the $\mathrm{BC}_{2} \mathrm{~F}_{1}$ plants, gene-positive plants were further advanced through selfing to develop $\mathrm{BC}_{2} \mathrm{~F}_{2}$ seeds. These $\mathrm{BC}_{2} \mathrm{~F}_{2}$ seeds were grown in the cage house in the subsequent season. $A$ total of $75 \mathrm{BC}_{2} \mathrm{~F}_{2}$ seeds were grown in the cage house, out of which 68 seeds germinated. These 68 plants were then validated using gene-linked molecular markers which exhibited desired amplicons of 830 linked to Co-4. The detailed results are depicted in Fig. 4. The results of the foreground selection in these 
plants revealed that for out of a total population of $68 \mathrm{BC}_{2} \mathrm{~F}_{2}$ plants, 46 plants (Plant Nos. 1, 2, 3, 4, 5, 6, 8, 10, 11, 12, 16, 17, 18, 19, $21,23,24,25,26,28,29,32,33,34,35,36,37,38,39,41,43,45,48,51,52,53,54,56,57,58,59,62,63,66,67$ and 68 ) were inferred to be Co-4 gene-positive. Overall the observed segregation ratio of gene-positive and gene-negative plants was $67.65 \%$ and $32.35 \%$ as against the expected perfect fit of $75 \%$ and $25 \%$, respectively.

\section{Selection of homozygous $\mathrm{BC}_{2} \mathrm{~F}_{3}$ derivatives for target gene $\mathrm{Co}-4$}

The seeds of gene-positive plants identified above were harvested as single plants and advanced as plant to row progenies to develop $\mathrm{BC}_{2} \mathrm{~F}_{3}$ plants. Ten seeds each of $46 \mathrm{BC}_{2} \mathrm{~F}_{3}$ plant progenies were sown as rows (Progeny 1 to 46 ) in the cage house. The information on total number of seeds harvested from each $\mathrm{BC}_{2} \mathrm{~F}_{2}$ gene-positive plant, number of seeds sown, germinated and segregation status for the target gene in each plant to row progeny of cross is presented in Table 1.

A total of $1259 \mathrm{BC}_{2} \mathrm{~F}_{3}$ seeds were harvested from 46 selected gene-positive $\mathrm{BC}_{2} \mathrm{~F}_{2}$ plants, out of which 9-10 seeds of each progeny were sown as single rows. A total of 457 seed of $46 \mathrm{BC}_{2} \mathrm{~F}_{2}$ plants were sown in 46 progeny rows out of which 427 germinated exhibiting a high seed germination of $93.4 \%$ in $\mathrm{BC}_{2} \mathrm{~F}_{3}$ seeds. Foreground selection with linked marker, $S Y 20$ in all the plants of the progeny row revealed lack of segregation in 16 progenies out of the total of 46 screened including $4,5,7,8,10,19,24,28,29,33,35$, 40, 42, 43, 45 and 46. These were inferred to be homozygous for the target gene, Co-4. Notably seed germination in these 16 progenies was observed cent per cent. In the remaining 30 progenies, segregation for the linked marker was observed. Progeny 1,2 , $3,6,9,11,12,13,16,17,18,20$ and 21 exhibited cent per cent germination and foreground selection indicated that out of 10 $\mathrm{BC}_{2} \mathrm{~F}_{3}$ plants in each row, $8,6,8,9,6,7,7,9,7,7,8,7$ and 6 plants, respectively exhibited presence of desired amplicon and were thus inferred to be heterozygous. In progeny $14,15,26,27,36$ and 38 , seed germination was observed 90 per cent and foreground selection showed that out of $9 \mathrm{BC}_{2} \mathrm{~F}_{3}$ plants in each row, 8, 8, 8, 7, 8 and 7 plants, respectively exhibited desired amplicon of 830 bp.

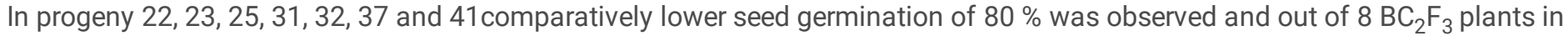
each row, only 7, 7, 7, 6 and 6 plants, respectively were gene-positive when foreground selection was done by using SY20 SCAR marker. In progeny 30,34, 39 and 44 showed only 4, 5, 6 and $6 \mathrm{BC}_{2} \mathrm{~F}_{3}$ plants, respectively in each row were gene-positive. Agarose gel showing presence/absence of amplification products ( 830 bp bands) of SCAR markers, SY2O in the parents and $427 \mathrm{BC}_{2} \mathrm{~F}_{3} \mathrm{Plants}$ in each row are depicted in Fig. 5, 6 and 7.

\section{Validation of $C_{0-4}$ imparted anthracnose resistance by using cultures of race 3 of $C$. lindemuthianum}

Validation of resistance in 16 selected homozygous lines for Co-4 gene was done by following detached pod and germinated seed dip method (repeated twice). Culture of $C$. lindemuthianum race-3 showing virulence on susceptible parent and known to be avirulent on Co-4 gene was used for screening and validation of anthracnose resistance of 16 selected homozygous lines carrying Co-4 gene as inferred by amplification of gene linked SCAR marker. Results of screening using both methods are presented in Table 2 and disease symptoms/reactions shown in Figure 7 (detached pod method) and Figure 8 (germinated seed dip method).

Screening for bean anthracnose using detached pod method revealed a disease score of ' 5 ' in the recipient parent, Arka Komal, whereas in resistant donor TO a disease score of ' 0 ' was recorded. All the $16 \mathrm{BC}_{2} \mathrm{~F}_{3}$ progenies inferred to be homozygous for the target gene $\mathrm{Co}-4$, recorded a disease score of ' 0 ' revealing there by resistant reaction of donor and 16 backcross progenies. Germinated seed dip method confirmed these results wherein also disease score of ' 0 ' was recorded in donor parent TO and 16 backcross progenies. These results clearly validated the presence of anthracnose resistance gene Co- 4 selected through linked marker SY2O and Co-4 gene imparted resistance to race 3 of $C$. lindemuthianum in all 16 selected progenies.

\section{Agronomic evaluation of the selected $16 \mathrm{BC}_{2} \mathrm{~F}_{4}$ progenies carrying Co-4 gene for 8 qualitative traits}

Agronomic evaluation for eight qualitative traits, scored visually revealed that all 16 Co-4 gene-positive homozygous lines were fixed for bushy growth habit as none of plant progenies exhibited segregation for the trait, whereas susceptible parent, Arka Komal has bush type growth habit and donor, parent TO (Co-4) has intermediate trailing habit. Pod shape of recipient parent, Arka Komal was straight/ slightly curved/ moderately curved and that of the donors, TO was straight/ slightly curved. Test cultures exhibited wide variation for pod shape ranging from straight to curved pods. Pods of Co-4 gene-positive homozygous sixteen progenies were graded straight in 4 progenies, namely AKTO 19, AKTO 28, AKTO 33 and AKTO 36 whereas pods of other 10 progenies, AKTO 4, AKTO 8, AKTO 10, AKTO 24, AKTO 29, AKTO 40, AKTO 42, AKTO 43, AKTO 45 and AKTO 46 were graded slightly curved. Pods of 2 
progenies, AKTO 5 and AKTO 7 were graded as moderately curved and some pods in AKTO 7 had curved pods along with moderately curved.

Pod colour at physiological maturity stage was noticed visually and pod colour of parent, Arka Komal and TO was observed green. All 16 Co-4 gene-positive progenies exhibited green pod colour at physiological maturity stage. Stem colour of parents and backcross progenies revealed that Arka Komal and donor, parent TO (Co-4) has green stem colour. All 16 Co-4 gene-positive backcross progenies also exhibited green stem colour. There is absence of any seed coat pattern in the seeds of recipient parent, Arka Komal whereas seed coat pattern of the donor parent, TO was observed to be mottled. All 16 Co-4 gene-positive back cross progenies were observed to have mottled seed coat pattern ranging from sparse to dense brown in colour. Seed coat colour of recipient parent, Arka Komal was observed grayish white to brown and donor parents, TO were noticed grayish white to beige. Seed coat colour of $\mathrm{Co}-4$ gene-positive back cross progenies exhibited a large variation ranging from grayish white to beige, grayish white to light beige, grayish white to dark brown, grayish white to golden brown, grayish white to pinkish brown and golden brown (Table 3). Presence of colour on around of hilum was observed in recipient parent, Arka Komal and donor parent, TO. The presence of brown colour around the hilum was noticed in all sixteen $\mathrm{Co}-4$ gene positive homozygous rows. Seeds brilliance of recipient parent, Arka Komal was observed shiny whereas donor parent, TO showed medium brilliance of seeds. Out of sixteen Co-4 gene-positive homozygous progenies, 5 (AKTO 29, AKTO 36, AKTO 40, AKTO 42 and AKTO 43) were found with shiny brilliance of seeds and 11 progenies (AKTO 4, AKTO 5, AKTO 7, AKTO 8, AKTO 10, AKTO 19, AKTO 24, AKTO 28, AKTO 33, AKTO 45 and AKTO 46) were observed to have medium seed brilliance.

\section{Agronomic evaluation of the selected $16 \mathrm{BC}_{2} \mathrm{~F}_{4}$ progenies carrying Co-4 gene for 9 quantitative traits}

\section{Analysis of variance}

The analysis of variance of data recorded on 9 quantitative agro-horticultural traits, viz. days to flowering initiation, days to 50 per cent flowering, plant height at 50 per cent flowering $(\mathrm{cm})$, number of branches/plant, number of pod bearing nodes/plant, pods/node, pods/plant, pod length $(\mathrm{cm})$ and green pod yield/plant $(\mathrm{g})$ revealed that mean sum of squares due to genotypes/treatments were significant for all the nine traits studied in the backcross progenies revealing thereby sufficient variation among test cultures for all the traits (Table 4 and 5).

\section{Performance of the parents and 16 Co-4 gene-positive $\mathrm{BC}_{2} \mathrm{~F}_{4}$ progenies}

Agronomic evaluation for 9 agro-horticultural traits revealed that the susceptible parent, Arka Komal is early flowering (35 days), whereas donor parents TO took 42 days for flowering initiation. Most of the Co-4 gene-positive homozygous progenies took intermediate time for flowering initiation that ranged from 36-42 days and none of these were found to be earlier flowering than the early parent, Arka Komal. However, 7 lines, AKTO 8, AKTO 10, AKTO 19, AKTO 24, AKTO 28, AKTO 42 and 43 were at par for duration of flowering initiation with early parent, Arka Komal. Remaining $9 \mathrm{Co}-4$ gene-positive derivatives exhibited significantly late flower initiation as compared to elite parent, Arka Komal (Table 5).

Fifty per cent flowering occurred in 37 days in recipient parent, Arka Komal and in 44 days in the donor parents, TO. Duration of 50 per cent flowering ranged from 38-44 days in the $16 \mathrm{Co}-4$ gene-positive backcross progenies. Most of the these took longer than early parent, Arka Komal for 50 per cent flowering except progenies AKTO 5, AKTO 10, AKTO 24, AKTO 28 and AKTO 42 that were statistically at par with the early flowering parent, Arka Komal.

The mean plant height of recipient parental line, Arka Komal at 50 per cent flowering was $45.83 \mathrm{~cm}$ whereas that of the donor parent, TO was $80.17 \mathrm{~cm}$ as this line have trailing type of growth habit. Most of the Co-4 gene-positive backcross progenies (10) exhibited shorter plant height as compared to the elite parent, Arka Komal ranging from 30.83 to $42.33 \mathrm{~cm}$. Progenies, AKTO 4, AKTO 8, AKTO 10, AKTO 19 and AKTO 24 had plant height at par with dwarf parent, Arka Komal. Progenies AKTO 7 and AKTO 43 were taller as compared to dwarf parent Arka Komal.

The mean branches/plant in the recipient parent, Arka Komal was 4.50 whereas the donor parent TO had 1.83 branches/plant. Mean number of branches/plant in Co-4 gene-positive backcross progenies varied from 2.50 to 4 in the 16 progenies. Seven progenies, AKTO 7, AKTO 8, AKTO 10, AKTO 29, AKTO 36, AKTO 40 and AKTO 45 had branches/plant at par with the elite parent, whereas remaining 9 progenies had lesser branches/plant than the better parent, Arka Komal. 
Mean pod bearing nodes/plant in the parental lines, Arka Komal and TO was 4.83 and 5.33, respectively. Pod bearing nodes/plant in the Co-4 gene-positive backcross progenies ranged from 4.17 to 8.0 revealing thereby a wide range of variation for this trait.

Progenies, AKTO 4 and AKTO 43 had significantly better pod bearing nodes/plant as compared to the better parent. Rest of the 14 progenies exhibited pod bearing nodes/plant at par with the elite parent, Arka Komal.

There was a narrow range of variation for mean number of pods/node. Arka Komal exhibited higher number of pods/node (2.50) as compared to donor parents TO (1.50). Thirteen Co-4 gene-positive back cross progenies out of 16 exhibited pods/node at par with the recipient parent, Arka Komal except progenies AKTO 7, AKTO 8 and AKTO 43 that had better pods/node than the elite parent, Arka Komal.

Average pod length in the recipient parental line Arka Komal was highest $(15.83 \mathrm{~cm})$ whereas in TO it was $9.53 \mathrm{~cm}$. The pod length of the Co-4 gene-positive progenies ranged from 11.37 to $14.20 \mathrm{~cm}$ and pods of all the progenies were shorter in length than the pods of better parent, Arka Komal. All the progenies exhibited pod length better than the Co-4 gene donor parent, TO.

Average pods/plant in recipient parent line, Arka Komal was 10.17 whereas in donor parent, TO it was 12.50. In donor parent TO the pods/plants were higher which might be due to its indeterminate and trailing growth habit. In Co-4 gene-positive back cross progenies the pods/plant varied from 6.17 to 14.67. Nine progenies, AKTO 4, AKTO 7, AKTO 8, AKTO 19, AKTO 24, AKTO 29, AKTO 33, AKTO 40 and AKTO 45 were at par with the elite parent Arka Komal. Two progenies AKTO 5 and AKTO 43 had significantly higher pods/ plant than the elite parent, Arka Komal whereas remaining 5 progenies were inferior to both the parents. Co- 4 gene donor parent, TO had better pods/plant and none of back cross progenies surpassed it for pods/plant.

Green pod yield/plant of the recipient parental line, Arka Komal was $67.67 \mathrm{~g}$ and that of donor parent, TO from three pickings was 35 $\mathrm{g}$, whereas Co-4 gene-positive back cross progenies had green pod yield/plant ranging from 28.33-65.0 g. Out of 16 progenies only 2 (AKTO 7 and AKTO 43) yielded at par with better parent, Arka Komal, whereas in the remaining 14 progenies, green pod yield/plant was lower than the elite parent.

Based on performance of 16 backcross progenies for all the traits, four best progenies performing at par with better parent and progenies performing better than elite parent were identified and are presented in Tables 6 . Overall agronomic performance indicated Co-4 gene-positive progenies AKTO 10, AKTO 19, AKTO 24 and AKTO 42 are the 4 best progenies for days to flower initiation that are at par with elite parent Arka Komal (Table 6). Similarly progenies AKTO 5, AKTO 10, AKTO 24 and AKTO 42 were the best four early flowering at par with the elite parent and hence can be used as donor of earliness along with resistance gene, Co4. Progenies, AKTO 4, AKTO8, AKTO 10 and AKTO 24 were at par with elite parent for plant height. Progenies, AKTO 7, AKTO 10, AKTO 36 and AKTO 40 were at par with elite parent for branches/plant. Similarly AKTO 5, AKTO 29, AKTO 40 and AKTO 46 were at par with elite parent for pod bearing nodes/plant whereas AKTO 4 and AKTO 43 were better than elite parent, Arka Komal. For pods/node, progenies AKTO 7, AKTO 8 and AKTO 43 were better than elite parent whereas progenies AKTO 5, AKTO 19, AKTO 24 and AKTO 43 were four best at par with elite parent. Progenies, AKTO 5 and AKTO 43 had better pods/plant than elite parent whereas progenies AKTO 7, AKTO 8, AKTO 33 and AKTO 40 were four best at par with elite parent. Only 2 progenies AKTO 7 and AKTO 43 were comparable in pod yield with elite parent. Overall 2 progenies namely AKTO 7 and AKTO 43 exhibited better pod bearing nodes/plant, pods/node and pods/plant and thus exhibited better green pod yield/plant comparable with elite parent Arka Komal.

\section{Discussion}

The crossability relationships between and within Phaseolus species have been extensively studied and reviewed (Smartt 1990; Debouck and Smartt 1995). Generally, there are strong barriers for interspecific hybridisation in Phaseolus, but between each cultigens and its wild ancestral type, almost full genetic compatibility exists (Mumba and Galwey 1998). Mumba and Galwey (1998) in their exhaustive study on cross compatibility between gene pools and evolutionary groups in Phaseolus vulgaris L. has clearly demonstrated that there is no general consistent tendency for pollinations between genotypes within a gene pool to be more successful than those between gene pools. In evolutionary groups (wild, landrace and bred), the crosses among landrace and bred genotypes, those within evolutionary classes had higher success rates than those between classes (47.2\% vs. $38.9 \%)$.

In the present study, the extent of crossability recorded (7.69\%) can easily be considered as comparatively low as the parent of the present study belong to the same evolutionary group i.e. bred genotypes should have shown higher compatibility as reported by the

Page 10/27 
aforementioned studies. However, the efficiency of crosssing depends on the fact that the stigma and pollen should be in very close contact as long as possible to ensure fertilization, as occurs with in the keel in natural selfing. Low cross compatibility in the present case can probably be ascribed to comparatively unfavorable factors for hybridization mentioned above under cage house as well as to the limited skill of person handling hybridisation. Similarly experience in manual hybridisation is likely to enhance the success rate of hybridisation programmes.

Overall in cross (AK × TO), the observed segregation ratio of gene-positive and gene-negative plants was $67.65 \%$ and $32.35 \%$ as against the expected perfect fit of $75 \%$ and $25 \%$, respectively. Such minor deviation can be a result of small sample size of population, differential seed development as well as a result of selection of seeds as only well filled seeds were advanced in the present case.

Marker assisted selection (MAS) and marker assisted backcross breeding (MABC) have received much attention as a viable method for crop improvement. In the case of disease resistance genes, molecular markers linked to genes of interest can be used to accumulate $\mathrm{R}$ genes in a single cultivar without laborious disease screening (Miklas et al. 2006). There is need to develop common bean varieties having resistance to bean anthracnose to counter threats of this disease on bean production. Chemical control is found to be expensive and generation of pathogen free seeds is often difficult in developing countries. So, the use of resistant genotypes appears to be the most biologically safe and cost-effective management strategy (Pastor-Corrales and Tu 1989).

In common beans, many earlier studies have also reported successful use of linked molecular markers for the selection of different bean anthracnose resistance genes in early as well as advanced segregating material. RAPD markers, OPY20 $830 \mathrm{C}(0.0 \mathrm{cM})$ and OPC08 $900 \mathrm{C}(9.7 \mathrm{cM})$ linked to the Co-4 gene have been identified by Arruda et al. (2000) in the coupling phase. It has been reported by them that the selection efficiency for resistant and susceptible plants was 100 per cent with RAPD marker OPY20 $830 \mathrm{C}$ due to its close linkage to locus Co-4 $(0.0 \pm 1.1 \mathrm{cM})$ and hence this marker can be used for screening gene harbouring plants in advanced generation ( $F_{6}$ or later) lines that are nearly homozygous. The SCAR marker, SY20 used in the present study for foreground selection of Co-4 gene has been developed from this RAPD marker (Queiroz et al. (2004) and therefore is also expected to be equally efficient in indirect selection for the gene, Co-4. Beraldo et al. (2009) has validated the specificity of the SY20 marker for the Co-4 locus while screening 42 parents and 76 elite lines developed by the common bean breeding programme of the Instituto Agronomico de Campinas (IAC, Campinas, SP, Brazil) with SY20. In the past successful marker assisted selection has been done by Alzate-Marin et al. (2004) for introgression of $\mathrm{Co}-4^{2}$ gene with RAPD markers OPH18 $1200 \mathrm{C}$. Similarly Gu et al. (2011) used five SCAR markers combinations $\left(\mathrm{SCA}_{1000}, \mathrm{SH} 18_{1100}, \mathrm{SAB} 3_{400}, \mathrm{SB} 12_{350}\right.$ and SCF10 1072$)$ successfully to screen 143 snap bean germplasm for bean anthracnose resistance. Ferreira et al. (2012) reported pyramiding of bean anthracnose resistance genes and resistance to potyvirus in the market class fabada beans using a set of seven molecular markers. Pyramids included genes Co-2 and Co-3/9. Boersma et al. (2013) observed marker assisted dissection of anthracnose resistance in dry bean cultivar, Morden003 previously reported to carry genes, Co-1, Co-2 and Co-4 on chromosomes Pv01, Pv11 and Pv06, respectively. Sousa et al. (2014) reported that cultivars or elite lines harboring the alleles $\mathrm{CO}_{-} 4^{2}, \mathrm{Co}-5$ and $\mathrm{Co}-6$, individually or in combination (pyramiding), are those with the highest resistance spectrum to anthracnose in Brazil. Moses (2015) used SCAR markers for pyramiding of three bean anthracnose genes (Co-4 ${ }^{2}, C^{-}$ 5 and $\mathrm{Co}-9$ ) and one Pythium resistance gene into susceptible common bean varieties, K132, NABE4, NABE13 and NABE14 by using a cascading pedigree gene pyramiding scheme. More recently, Manjula et al. (2016) used 15 SCAR markers to identify anthracnose resistance genes in 40 French bean accessions and reported successful amplification of six SCAR markers namely SAS13, SBB14, SC08, SF10, SW12 and SZ04 to detect presence of Co-4², Co-4, Co-10, Co-3/Co-9 and Co-6 genes. Kamiri et al. (2021) tested four SCAR markers in the present work ( $S H 18$ and SBB-14 for Co-42, SAB-03 for Co-5, and SY-20 for Co-4), have shown to be useful for marker assisted selection of the target resistant genes. They were found specific for the linked loci. SH18 was shown to be specifically linked to $\mathrm{Co}-4^{2}$ and some other did not discriminate alleles from the same locus.

One of the major constraints during breeding for disease resistance is that donor lines are carrier of undesirable attributes that subsequently lead to development of poor performing progenies from crosses of elite parents with gene donors (Hospital 2005). Various approaches are followed to reduce this junk and linkage drag including marker-assisted backcross breeding (MABC) with foreground and accompanying background selection to restore the elite background (Fukuoka et al. 2009). Under such situations, one of the alternative approaches could be pre breeding efforts to bring such important disease resistance genes into comparatively better and/or elite backgrounds, and to use products of such breeding efforts as donors of the genes rather than the original inferior donors. 
Studies on race spectrum of bean anthracnose have revealed presence of 27 races in all from North Western Himalayan region, out of which 19 are reported to be present in Himachal Pradesh (Sharma et al. 2019). Apart from race 3, Co-4 gene is reported to impart resistance against most of the other Indian races including 115, 513, 515, 529, 537, 615 and 631 (Pathania et al. 2006). Out of these 8 races, four new races $(115,537,615$ and 631$)$ have been reported for the first time from Himachal Pradesh, India which had not been reported earlier from the other regions of the world (Sharma et al. 2007). Therefore, deployment of the gene Co-4 is more relevant in this region as the lines developed under this study harbouring $\mathrm{Co}-4$ have potential to impart resistance against 8 prevalent races, four of which are new and specific to the region. Therefore, deployment of the gene Co-4 is most relevant to achieve durable and efficient resistance against bean anthracnose.

In literature, various methods of artificial disease screening for anthracnose resistance are mentioned including seedling inoculation, germinated seed dip inoculation, detached pod and detached leaf methods (Tu 1986). Of these detached leaf and pod method have been reported to be the best by Bigirimana and Hofte (2001). Different methods have associated advantages and disadvantages. In detached leaf/pod method, spores are uniformly distributed over the leaf/pod area which provides accuracy and promptness for screening because disease symptoms appear uniformly on leaf/pod area. However, the results of the present study clearly demonstrated equal efficiency and accuracy of both, detached pod and germinated seed dip methods as similar disease reactions were obtained on test cultures using both methods.

As discussed above, SCAR marker SY2O linked to gene, Co-4 is reported to be used successfully to select gene-positive progenies in different bean breeding programmes throughout the world (Queiroz et al. 2004 and Vallejo and Kelly 2001). As far accuracy and efficiency of markers is concerned, the present study has clearly indicated the cent per cent accuracy and efficiency of SCAR markers SY2O in selecting the gene, $\mathrm{Co}-4$ as indicated by the validation of imparted resistance in all 16 progenies. This is easily understandable in case of marker SY20 that is known to be tightly linked with the gene $\mathrm{Co}-4$ gene has been developed from OPY $20_{830 \mathrm{C}}$ RAPD marker at a distance of $0.0 \pm 1.1 \mathrm{cM}$ (Queiroz et al. (2004) and therefore is also expected to be equally efficient in indirect selection for the gene, Co-4.

In French bean pod shape is gaining more importance as an important agro-morphological attribute because of its role in post harvest processing. Straight pods are preferred more for easy handling and transport. Hence four Co-4 gene-positive progenies exhibiting straighter pods can be likely used as donor of traits in addition to resistance gene, Co-4. $\mathrm{BC}_{2} \mathrm{~F}_{4}$ progenies AKTO 4, AKTO 5, AKTO 7 and AKTO 43 of cross were identified as having better elite background along with the target gene can be potentially used as donor of various traits in addition to bean anthracnose resistance gene, Co-4 as the likelihood of such parents contributing poor traits would be far less than the original donors and associated linkage drag can also be minimized.

\section{Conclusion}

The present study revealed the possibility of hybridisation and clearly validated the use of SCAR marker SY20 for foreground selection in backcross breeding and tracking the genes in segregating populations of beans in selecting the gene Co-4. Comparable/better performance for some agro-horticultural traits revealed elite background of the identified stable homozygous derivatives $\left(\mathrm{BC}_{2} \mathrm{~F}_{4}\right)$ for gene, Co-4 indicating success of backcross programme undertaken in the current study. The identified derivatives of cross can be further advanced using backcrossing to further improve the background and/ used as donors of resistance genes in the future bean breeding programmes.

\section{Declarations}

Acknowledgements The first author is thankful to Department of Agricultural Biotechnology, CSK HPKV, Palampur, Himachal Pradesh, India.

Author contribution Bansuli formulated the initial data and RK Kapila corrected and wore the final manuscript.

Conflict of Interest All the authors declare that they have no conflict of interest in the publication.

\section{References}

Page $12 / 27$ 
1. Alzate-Marin AL, Arruda KM, de Souza KA, de Barros EG, Moreira MA (2004) Introgression of Co-42 and Co-5 anthracnose resistance genes into 'carioca' common bean cultivars. Crop Breeding and Applied Biotechnology 4(4):446-451

2. Arruda MCC, Alzate-Marin AL, Chagas JM, Moreira MA, Barros EG (2000) Identification of random amplified polymorphic DNA markers linked to the Co-4 resistance gene to Colletotrichum lindemuthianum in common bean. Phytopathology 90:758-761

3. Bennett MD, Leitch IJ (1995) Nuclear DNA amounts in angiosperms. Ann Botany 76(2):113-176

4. Beraldo ALA, Colombo CA, Chiorato AF, Ito MF, Carbonell SAM (2009) Use of SCAR markers in common bean breeding for anthracnose resistance. Bragantia 68(1):53-61

5. Bigirimana J, Hofte M (2001) Bean anthracnose: Inoculation methods and influence of plant stage on resistance of Phaseolus vulgaris cultivars. Phytopathology 149:403-408

6. Boersma JG, Conner RL, Balasubramanian PM, Yu K, Hou A (2013) Marker-assisted dissection of anthracnose resistance in the dry bean cultivar Morden003. Can J Plant Sci 93(6):1115-1123

7. Broughton WJ, Hernandez G, Blair M, Beebe S, Gepts P, Vanderleyden J (2003) Beans (Phaseolus spp.)-model food legumes. Plant Soil 252(1):55-128

8. Campa A, Rodriguez-Suarez C, Giraldez R, Ferreira JJ (2014) Genetic analysis of the response to eleven Colletotrichum lindemuthianum races in a RIL population of common bean (Phaseolus vulgaris L.). BMC Plant Biol 14:115

9. CGIAR Common Bean (2012) [accessed on Day December 2021]. Available online:http://www.cgiar.org/our-research/cropfactsheets/beans/

10. de Lima Castro SA, Goncalves-Vidigal MC, Gilio TAS, Giselly, Lacanallo GF, Valentini G, Martins VSR, Song Q, Galván MZ, Hurtado-Gonzales OP, Pastor-Corrales MA (2017) Genetics and mapping of a new anthracnose resistance locus in Andean common bean Paloma. BMC Genomics 18:306

11. Debouck DG, Smartt J (1995) Beans Phaseolus spp. (Leguminosae Papilionatae). In: Simmonds, N.W., Smartt, J. (eds.). Evolution of Crop Plants (Second Edition). Longman, London, United Kingdom 287-294

12. Drijfhout E, Davis JHC (1989) Selection of a new set of a homogenously reacting beam differentials to differentiate races of Colletotrichum lindemuthianum. Plant Pathol 38:391-396

13. FAO (Food and Agriculture Organization) (2016) www.faostat.fao.org [15th December 2021]

14. FAO (Food and Agriculture Organization) (2017) www.faostat.fao.org [15th December 2021]

15. Ferreira JJ, Campa A, Perez-Vega E, Rodriguez-Suarez C, Giraldez R (2012) Introgression and pyramiding into common bean market class fabada of genes conferring resistance to anthracnose and poty virus. Theor Appl Genet 124(4):777-788

16. Freyre R, Skroch PW, Geffroy V, Adam-Blondon AF, Shirmohamadali A, Johnson WC, Llaca V, Nodari RO, Pereira PA, Tsai SM, Tohme J, Dron M, Nienhuis J, Vallejos CE, Gepts P (1998) Towards an integrated linkage map of common bean. 4. Development of a core linkage map and alignment of RFLP maps. Theor Appl Genet 97:847-856

17. Fukuoka S, Saka N, Koga H, Ono K, Shimizu T, Ebana K, Hayashi N, Takahashi A, Hirochika H, Okuno K (2009) Loss of function of a proline-containing protein confers durable disease resistance in rice. Science 325:998-1001

18. Goncalves-Vidigal MC, Meirelles AC, Poletine JP, Sousa LL, Cruz AS, Nunes MP, Lacanallo GF, Vidigal Filho PS (2012) Genetic analysis of anthracnose resistance in Pitanga dry bean cultivar. Plant Breeding 131:423-429

19. Gu Yu, Han Q, Wang W, Li S, Sun D, Wu F (2011) Application of common bean anthracnose resistance gene SCAR markers in snap bean disease resistance identification. Acta Horticulturae Sinica 38(5):911-920

20. Hospital F (2005) Selection in backcross programmes. Philosophical Transactions of the Royal Society B 360:1503-1511

21. Kamiri AK, Arunga EE, Rotich F, Otsyula R (2021) Response of French bean genotypes to Colletotrichum lindemuthianum and evaluation of their resistance using SCAR markers. Afr J Biotechnol 20(2):51-65

22. Kaur S, Narpinder S, Navdeep SS, Rana JC (2009) Diversity in properties of seed and flour of kidney bean germplasm. Food Chem 117(2):282-289

23. Kelly JD, Vallejo VA (2004) A comprehensive review of the major genes conditioning resistance to anthracnose in common bean. Horticultural Science 39(6):1196-1207

24. Khetan S, Singh N, Kaur A, Rana JC (2015) Structural and functional characterization of kidney bean and field pea protein isolates: a comparative study. Food Hydrocolloids 43:679-689

Page $13 / 27$ 
25. Kwak M, Gepts P (2009) Structure of genetic diversity in the two major gene pools of common bean (Phaseolus vulgaris $L$. Fabaceae). Theor Appl Genet 118:979-992

26. Limongelli G, Laghetti G, Perrino P, Piergiovanni AR (1996) Variation of seed storage proteins in landraces of common bean (Phaseolus vulgaris L.) from Basilicata, southern Italy. Euphytica 92:393-399

27. Manjula V, Shyamalamma S, Hosamani A, Geetha MS (2016) Validation of SCAR markers linked to anthracnose resistant in French bean (Phaseolus vulgaris L.) germplasm. Green Farming 7(2):379-382

28. Mayee CD, Dattar VV (1986) Phytopathometry. Technical Bulletin-1. Marathwada Agricultural University, Parbhani, pp 88-89

29. Miklas PN, Kelly JD, Beebe SE, Blair MW (2006) Common bean breeding for resistance against biotic and abiotic stresses: from classical to MAS breeding. Euphytica 147:105-131

30. Mishra S, Sharma MK, Singh M, Yadav SK (2010) Genetic diversity of French bean (Bush type) genotypes in northwest Himalayas. Indian Journal of Plant Genetic Resources 23(3):285-287

31. Moses K (2015) Pyramiding bean anthracnose and root rot resistance genes into susceptible market class common bean varieties using SCAR markers. Ph D Thesis, Makerere University, Kampala, Uganda

32. Mumba LE, Galway NW (1998) Compatibility of crosses between gene pools and evolutionary classes in the common bean (Phaseolus vulgaris L.). Genet Resour Crop Evol 45:69-80

33. Murray HG, Thompson WF (1980) Rapid isolation of high molecular weight DNA. Nucleic Acids Res 8:4321-4325

34. Nodari RO, Tsai SM, Guzman P, Gilbertson RL, Gepts P (1993) Toward an integrated linkage map of common bean. III. Mapping genetic factors controlling host-bacteria interactions. Genetics 134:341-350

35. Panse VG, Sukhatme PV (1984) Statistical methods for agricultural workers. ICAR, New Delhi

36. Pastor-Corrales MA, TU JC (1989) In: Schwartz HF, Pastor-Corrales MA (eds) Anthracnose. In- Bean production problems in the tropics. CIAT, Cali, pp 77-104

37. Pathania A, Sharma PN, Sharma OP, Chahhota RK, Padder BA, Sharma P (2006) Evaluation of resistance sources and inheritance of resistance in kidney bean to Indian virulences of Colletotrichum lindemuthianum - evaluation of resistance in bean to anthracnose. Euphytica 149(1/2):97-103

38. Pedrosa-Harand A, Porch T, Gepts P (2008) Standard nomenclature for common bean chromosomes and linkage groups. Annual Report of Bean Improvement Cooperative 51: 106-107

39. Peloso MJ Del (1992) Antracnose do feijoeiro no Estado de Minas Gerais-Brasil. La antracnosis del frijol comun, Phaseolusvulgaris, en America Latina. Doc. de Trabajo No. 113. M. Pastor-Corrales. ed. CIAT, Cali, Colombia, pp 86-108

40. Pujola M, Farreas A, Casanas F (2007) Protein and starch content of raw, soaked and cooked beans (Phaseolus vulgaris L.). Food Chem 102:1034-1041

41. Queiroz VT, Sousa CS, Costa MR, Sanglad DA, Arruda KMA, Souza TLPO, Ragagnin VA, Barros EG, Moreira MA (2004) Development of SCAR markers linked to common bean anthracnose resistance genes Co-4 and Co-6. Annual Report of the Bean improvement Cooperative, Michigan 47: 249-250

42. Sharma N, Kumari N, Sharma SK, Padder BA, Sharma PN (2019) Investigating the virulence and genetic diversity of Colletotrichum lindemuthianum populations distributed in the North Western Himalayan hill states. Journal of Plant Pathology. https://doi.org/10.1007/s42161-019-00269-8

43. Sharma PN, Kumar A, Sharma OP, Sud D, Tyagi PD (1999) Pathogenic variability in Colletotrichum lindemuthianum and evaluation of resistance in Phaseolus vulgaris in the north western Himalayan region of India. Journal of Phtytopathology $147: 41-45$

44. Sharma PN, Padder BA, Sharma OP, Pathania A, Sharma P (2007) Pathological and molecular diversity in Colletotrichum lindemuthianum (bean anthracnose) across Himachal Pradesh, a North-Western Himalayan state of India. Australas Plant Pathol 36(2):191-197

45. Singh N, Kaur S, Rana JC, Nakaura Y, Inouchi N (2012) Isoamylase debranched fractions and granule size in starches from kidney bean germplasm: distribution and relationship with functional properties. Food Res Int 47:174-181

46. Smartt J (1990) Grain legumes. Evolution and genetic resources. Cambridge University Press, Cambridge, p 379

47. Sousa LL, Cruz AS, VidigalFilho PS, Vallejo VA, Kelly JD, Goncalves-Vidigal MC (2014) Genetic mapping of the resistance allele Co- $5^{2}$ to Colletotrichum lindemuthianum in the common bean MSU 7-1 line. Aust J Crop Sci 8(2):317-323

Page 14/27 
48. Tu JC (1986) Anthracnose screening techniques for beans. Can J Plant Sci 66:805-809

49. Vallejo V, Kelly JD (2001) Development of a SCAR marker linked to the Co5 locus in common bean. Annual Report of Bean Improvement Cooperative 44: 121-122

\section{Tables}

Table 1 Number of seeds harvested from $\mathrm{BC}_{2} \mathrm{~F}_{2}$ gene-positive plant, seeds sown, number of seeds germinated and segregation status in each $\mathrm{BC}_{2} \mathrm{~F}_{3}$ progeny 


\begin{tabular}{|c|c|c|c|c|c|c|c|}
\hline \multirow[t]{2}{*}{$\begin{array}{l}\text { Progeny } \\
\text { number }\end{array}$} & \multirow{2}{*}{$\begin{array}{l}\text { Number of seeds } \\
\text { harvested from } \\
\mathrm{BC}_{2} \mathrm{~F}_{2} \text { gene-positive } \\
\text { plant }\end{array}$} & \multirow{2}{*}{$\begin{array}{l}\text { Number } \\
\text { of } \\
\text { seeds } \\
\text { sown }\end{array}$} & \multirow[t]{2}{*}{$\begin{array}{l}\text { Number of } \\
\text { seeds } \\
\text { germinated }\end{array}$} & \multirow[t]{2}{*}{$\begin{array}{l}\text { Seed } \\
\text { Germination } \\
\text { (\%) }\end{array}$} & \multicolumn{2}{|c|}{$\begin{array}{l}\text { Marker status ( } 830 \mathrm{bp} \\
\text { band for Arka Komal } \times \text { TO } \\
\text { cross combination) }\end{array}$} & \multirow[t]{2}{*}{$\begin{array}{l}\text { Segregation status } \\
\text { of the progeny }\end{array}$} \\
\hline & & & & & $\begin{array}{l}\text { Number of } \\
\text { gene- } \\
\text { positive } \\
\mathrm{BC}_{2} \mathrm{~F}_{3} \\
\text { plants }\end{array}$ & $\begin{array}{l}\text { Number of } \\
\text { gene- } \\
\text { negative } \\
\mathrm{BC}_{2} \mathrm{~F}_{3} \\
\text { plants }\end{array}$ & \\
\hline $\begin{array}{l}\text { Progeny } \\
1\end{array}$ & 13 & 10 & 10 & 100 & 8 & 2 & Segregating \\
\hline $\begin{array}{l}\text { Progeny } \\
2\end{array}$ & 34 & 10 & 10 & 100 & 6 & 4 & Segregating \\
\hline $\begin{array}{l}\text { Progeny } \\
3\end{array}$ & 22 & 10 & 10 & 100 & 8 & 2 & Segregating \\
\hline $\begin{array}{l}\text { Progeny } \\
4\end{array}$ & 33 & 10 & 10 & 100 & 10 & 0 & Non segregating \\
\hline $\begin{array}{l}\text { Progeny } \\
5\end{array}$ & 32 & 10 & 10 & 100 & 10 & 0 & Non segregating \\
\hline $\begin{array}{l}\text { Progeny } \\
6\end{array}$ & 43 & 10 & 10 & 100 & 9 & 1 & Segregating \\
\hline $\begin{array}{l}\text { Progeny } \\
7\end{array}$ & 29 & 10 & 10 & 100 & 10 & 0 & Non segregating \\
\hline $\begin{array}{l}\text { Progeny } \\
8\end{array}$ & 37 & 10 & 10 & 100 & 10 & 0 & Non segregating \\
\hline $\begin{array}{l}\text { Progeny } \\
9\end{array}$ & 13 & 10 & 10 & 100 & 6 & 4 & Segregating \\
\hline $\begin{array}{l}\text { Progeny } \\
10\end{array}$ & 37 & 10 & 10 & 100 & 10 & 0 & Non segregating \\
\hline $\begin{array}{l}\text { Progeny } \\
11\end{array}$ & 17 & 10 & 10 & 100 & 7 & 3 & Segregating \\
\hline $\begin{array}{l}\text { Progeny } \\
12\end{array}$ & 55 & 10 & 10 & 100 & 7 & 3 & Segregating \\
\hline $\begin{array}{l}\text { Progeny } \\
13\end{array}$ & 18 & 10 & 10 & 100 & 9 & 1 & Segregating \\
\hline $\begin{array}{l}\text { Progeny } \\
14\end{array}$ & 18 & 10 & 9 & 90 & 8 & 1 & Segregating \\
\hline $\begin{array}{l}\text { Progeny } \\
15\end{array}$ & 44 & 10 & 9 & 90 & 8 & 1 & Segregating \\
\hline $\begin{array}{l}\text { Progeny } \\
16\end{array}$ & 37 & 10 & 10 & 100 & 7 & 3 & Segregating \\
\hline $\begin{array}{l}\text { Progeny } \\
17\end{array}$ & 17 & 10 & 10 & 100 & 7 & 3 & Segregating \\
\hline $\begin{array}{l}\text { Progeny } \\
18\end{array}$ & 24 & 10 & 10 & 100 & 8 & 2 & Segregating \\
\hline $\begin{array}{l}\text { Progeny } \\
19\end{array}$ & 18 & 10 & 10 & 100 & 10 & 0 & Non segregating \\
\hline $\begin{array}{l}\text { Progeny } \\
20\end{array}$ & 16 & 10 & 10 & 100 & 7 & 3 & Segregating \\
\hline $\begin{array}{l}\text { Progeny } \\
21\end{array}$ & 73 & 10 & 10 & 100 & 6 & 4 & Segregating \\
\hline
\end{tabular}




\begin{tabular}{|c|c|c|c|c|c|c|c|}
\hline $\begin{array}{l}\text { Progeny } \\
22\end{array}$ & 24 & 10 & 7 & 70 & 5 & 2 & Segregating \\
\hline $\begin{array}{l}\text { Progeny } \\
23\end{array}$ & 63 & 10 & 8 & 80 & 7 & 1 & Segregating \\
\hline $\begin{array}{l}\text { Progeny } \\
24\end{array}$ & 19 & 10 & 10 & 100 & 10 & 0 & Non segregating \\
\hline $\begin{array}{l}\text { Progeny } \\
25\end{array}$ & 24 & 10 & 8 & 80 & 4 & 4 & Segregating \\
\hline $\begin{array}{l}\text { Progeny } \\
26\end{array}$ & 26 & 10 & 9 & 90 & 8 & 1 & Segregating \\
\hline $\begin{array}{l}\text { Progeny } \\
27\end{array}$ & 16 & 10 & 9 & 90 & 7 & 2 & Segregating \\
\hline $\begin{array}{l}\text { Progeny } \\
28\end{array}$ & 16 & 10 & 10 & 100 & 10 & 0 & Non segregating \\
\hline $\begin{array}{l}\text { Progeny } \\
29\end{array}$ & 12 & 9 & 9 & 100 & 9 & 0 & Non segregating \\
\hline $\begin{array}{l}\text { Progeny } \\
30\end{array}$ & 30 & 10 & 7 & 70 & 4 & 3 & Segregating \\
\hline $\begin{array}{l}\text { Progeny } \\
31\end{array}$ & 13 & 10 & 8 & 80 & 7 & 1 & Segregating \\
\hline $\begin{array}{l}\text { Progeny } \\
32\end{array}$ & 38 & 10 & 8 & 80 & 7 & 1 & Segregating \\
\hline $\begin{array}{l}\text { Progeny } \\
33\end{array}$ & 25 & 10 & 10 & 100 & 10 & 0 & Non segregating \\
\hline $\begin{array}{l}\text { Progeny } \\
34\end{array}$ & 30 & 10 & 8 & 80 & 5 & 3 & Segregating \\
\hline $\begin{array}{l}\text { Progeny } \\
35\end{array}$ & 26 & 10 & 10 & 100 & 10 & 0 & Non segregating \\
\hline $\begin{array}{l}\text { Progeny } \\
36\end{array}$ & 46 & 10 & 9 & 90 & 8 & 1 & Segregating \\
\hline $\begin{array}{l}\text { Progeny } \\
37\end{array}$ & 22 & 10 & 8 & 80 & 6 & 2 & Segregating \\
\hline $\begin{array}{l}\text { Progeny } \\
38\end{array}$ & 16 & 10 & 9 & 90 & 7 & 2 & Segregating \\
\hline $\begin{array}{l}\text { Progeny } \\
39\end{array}$ & 16 & 10 & 7 & 70 & 6 & 1 & Segregating \\
\hline $\begin{array}{l}\text { Progeny } \\
40\end{array}$ & 40 & 10 & 10 & 100 & 10 & 0 & Non segregating \\
\hline $\begin{array}{l}\text { Progeny } \\
41\end{array}$ & 21 & 10 & 8 & 80 & 6 & 2 & Segregating \\
\hline $\begin{array}{l}\text { Progeny } \\
42\end{array}$ & 18 & 10 & 10 & 100 & 10 & 0 & Non segregating \\
\hline $\begin{array}{l}\text { Progeny } \\
43\end{array}$ & 24 & 10 & 10 & 100 & 10 & 0 & Non segregating \\
\hline $\begin{array}{l}\text { Progeny } \\
44\end{array}$ & 16 & 10 & 7 & 70 & 6 & 1 & Segregating \\
\hline $\begin{array}{l}\text { Progeny } \\
45\end{array}$ & 21 & 10 & 10 & 100 & 10 & 0 & Non segregating \\
\hline $\begin{array}{l}\text { Progeny } \\
46\end{array}$ & 30 & 10 & 10 & 100 & 10 & 0 & Non segregating \\
\hline
\end{tabular}


Table 2 Disease score and reaction of 16 selected $\mathrm{BC}_{2} \mathrm{~F}_{3}$ homozygous lines for Co-4 gene against race 3 of Colletotrichum lindemuthianum using detached pod and germinated seed dip methods

\begin{tabular}{|c|c|c|c|c|}
\hline \multirow{3}{*}{ Homozygous lines/ rows no. } & \multirow[t]{3}{*}{ Homozygous lines } & \multicolumn{2}{|c|}{ Disease score } & \multirow[t]{3}{*}{ Disease reaction } \\
\hline & & Detached & Germinated & \\
\hline & & pod method & seed dip method & \\
\hline Row 4 & AKTO 4 & 0 & 0 & Resistant \\
\hline Row 5 & AKTO 5 & 0 & 0 & Resistant \\
\hline Row 7 & AKTO 7 & 0 & 0 & Resistant \\
\hline Row 8 & AKTO 8 & 0 & 0 & Resistant \\
\hline Row 10 & AKTO 10 & 0 & 0 & Resistant \\
\hline Row 19 & AKTO 19 & 0 & 0 & Resistant \\
\hline Row 24 & AKTO 24 & 0 & 0 & Resistant \\
\hline Row 28 & AKTO 28 & 0 & 0 & Resistant \\
\hline Row 29 & AKTO 29 & 0 & 0 & Resistant \\
\hline Row 33 & AKTO 33 & 0 & 0 & Resistant \\
\hline Row 36 & AKTO 36 & 0 & 0 & Resistant \\
\hline Row 40 & AKTO 40 & 0 & 0 & Resistant \\
\hline Row 42 & AKTO 42 & 0 & 0 & Resistant \\
\hline Row 43 & AKTO 43 & 0 & 0 & Resistant \\
\hline Row 45 & AKTO 45 & 0 & 0 & Resistant \\
\hline Row 46 & AKTO 46 & 0 & 0 & Resistant \\
\hline \multicolumn{5}{|l|}{ Control } \\
\hline Arka Komal & & 5 & 5 & Susceptible \\
\hline TO & & 0 & 0 & Resistant \\
\hline
\end{tabular}

Table 3 Characteristics of the parents and 16 Co- 4 gene-positive $\mathrm{BC}_{2} \mathrm{~F}_{4}$ progenies for 8 qualitative agro-horticultural traits 


\begin{tabular}{|c|c|c|c|c|c|c|c|c|}
\hline $\begin{array}{l}\text { Parents/ } \\
\mathrm{BC}_{2} \mathrm{~F}_{4} \text { proginies }\end{array}$ & $\begin{array}{l}\text { Growth } \\
\text { habit }\end{array}$ & Pod shape & $\begin{array}{l}\text { Pod } \\
\text { colour at } \\
\text { picking } \\
\text { stage }\end{array}$ & $\begin{array}{l}\text { Stem } \\
\text { colour }\end{array}$ & $\begin{array}{l}\text { Seed } \\
\text { coat } \\
\text { pattern }\end{array}$ & $\begin{array}{l}\text { Seed coat } \\
\text { colour }\end{array}$ & $\begin{array}{l}\text { Presence of } \\
\text { colour on } \\
\text { around of } \\
\text { hilum }\end{array}$ & $\begin{array}{l}\text { Brilliance } \\
\text { of seed }\end{array}$ \\
\hline AKTO 4 & Bush type & Slightly curved & Green & Green & Mottled & $\begin{array}{l}\text { Greyish } \\
\text { white }\end{array}$ & Present & Medium \\
\hline AKTO 5 & Bush type & $\begin{array}{l}\text { Moderately } \\
\text { curved }\end{array}$ & Green & Green & Mottled & $\begin{array}{l}\text { Greyish } \\
\text { white to } \\
\text { dark } \\
\text { brown }\end{array}$ & Present & Medium \\
\hline AKTO 7 & Bush type & $\begin{array}{l}\text { Moderately } \\
\text { curved/ curved }\end{array}$ & Green & Green & Mottled & $\begin{array}{l}\text { Greyish } \\
\text { white to } \\
\text { beige }\end{array}$ & Present & Medium \\
\hline AKTO 8 & Bush type & Slightly curved & Green & Green & Mottled & $\begin{array}{l}\text { Greyish } \\
\text { white to } \\
\text { beige }\end{array}$ & Present & Medium \\
\hline AKTO 10 & Bush type & Slightly curved & Green & Green & Mottled & $\begin{array}{l}\text { Greyish } \\
\text { white to } \\
\text { brown }\end{array}$ & Present & Medium \\
\hline AKTO 19 & Bush type & Straight & Green & Green & Mottled & $\begin{array}{l}\text { Greyish } \\
\text { white }\end{array}$ & Present & Medium \\
\hline AKTO 24 & Bush type & Slightly curved & Green & Green & Mottled & $\begin{array}{l}\text { Greyish } \\
\text { white to } \\
\text { light } \\
\text { beige }\end{array}$ & Present & Medium \\
\hline AKTO 28 & Bush type & Straight & Green & Green & Mottled & $\begin{array}{l}\text { Greyish } \\
\text { white to } \\
\text { light } \\
\text { beige }\end{array}$ & Present & Medium \\
\hline AKTO 29 & Bush type & Slightly curved & Green & Green & Mottled & $\begin{array}{l}\text { Greyish } \\
\text { white to } \\
\text { beige }\end{array}$ & Present & Shiny \\
\hline AKTO 33 & Bush type & Straight & Green & Green & Mottled & $\begin{array}{l}\text { Greyish } \\
\text { white to } \\
\text { Golden } \\
\text { brown }\end{array}$ & Present & Medium \\
\hline AKTO 36 & Bush type & Straight & Green & Green & Mottled & $\begin{array}{l}\text { Greyish } \\
\text { white to } \\
\text { Golden } \\
\text { brown }\end{array}$ & Present & Shiny \\
\hline AKTO 40 & Bush type & Slightly curved & Green & Green & Mottled & $\begin{array}{l}\text { Greyish } \\
\text { white to } \\
\text { Golden } \\
\text { brown }\end{array}$ & Present & Shiny \\
\hline AKTO 42 & Bush type & Slightly curved & Green & Green & Mottled & $\begin{array}{l}\text { Greyish } \\
\text { white to } \\
\text { dark } \\
\text { brown }\end{array}$ & Present & Shiny \\
\hline AKTO 43 & Bush type & Slightly curved & Green & Green & Mottled & $\begin{array}{l}\text { Greyish } \\
\text { white to } \\
\text { beige }\end{array}$ & Present & Shiny \\
\hline AKTO 45 & Bush type & Slightly curved & Green & Green & Mottled & $\begin{array}{l}\text { Greyish } \\
\text { white to } \\
\text { pinkish } \\
\text { brown }\end{array}$ & Present & Medium \\
\hline AKTO 46 & Bush type & Slightly curved & Green & Green & Mottled & $\begin{array}{l}\text { Greyish } \\
\text { white to }\end{array}$ & Present & Medium \\
\hline
\end{tabular}


Parents

\begin{tabular}{lllllllll} 
Arka Komal & Bush type & $\begin{array}{l}\text { Straight/ } \\
\text { Slightly curved/ } \\
\text { Moderately } \\
\text { curved }\end{array}$ & Green & Green & Absent & $\begin{array}{l}\text { Greyish } \\
\text { white to } \\
\text { brown }\end{array}$ & Present & Shiny \\
\hline TO & $\begin{array}{l}\text { Intermediate } \\
\text { trailing }\end{array}$ & $\begin{array}{l}\text { Straight/ } \\
\text { Slightly curved }\end{array}$ & Green & Green & Mottled & $\begin{array}{l}\text { Greyish } \\
\text { white to } \\
\text { beige }\end{array}$ & Present & Medium \\
\hline
\end{tabular}

Table 4 Analysis of variance for nine quantitative agro-horticultural traits in Co-4 gene-positive backcross progenies

\begin{tabular}{|c|c|c|c|c|c|c|c|c|c|}
\hline Source & $\begin{array}{l}\text { Days to } \\
\text { flowering } \\
\text { Initiation }\end{array}$ & $\begin{array}{l}\text { Days to } \\
50 \text { per } \\
\text { cent } \\
\text { flowering }\end{array}$ & $\begin{array}{l}\text { Plant } \\
\text { height at } \\
50 \text { per } \\
\text { cent } \\
\text { flowering } \\
\text { (cm) }\end{array}$ & $\begin{array}{l}\text { Branches } \\
\text { /plant }\end{array}$ & $\begin{array}{l}\text { Pod bearing } \\
\text { nodes/plant }\end{array}$ & Pods/Node & $\begin{array}{l}\text { Pod } \\
\text { length } \\
\text { (cm) }\end{array}$ & Pods/plant & $\begin{array}{l}\text { Green pod } \\
\text { yield/plant } \\
\text { (g) }\end{array}$ \\
\hline d.f & & & & & & & & & \\
\hline$M_{r} \quad 2$ & 9.40 & 5.68 & 52.06 & 0.17 & 0.72 & 0.37 & 1.62 & 5.56 & 67.04 \\
\hline $\begin{array}{ll}M_{g} & 17\end{array}$ & $17.83^{*}$ & $18.20^{*}$ & $372.73^{\star}$ & $1.14^{\star}$ & $2.90^{*}$ & $0.74^{\star}$ & $5.77^{\star}$ & $21.81^{*}$ & $484.24^{*}$ \\
\hline$M_{e} \quad 34$ & 2.44 & 2.51 & 6.70 & 0.33 & 0.43 & 0.16 & 0.63 & 2.03 & 32.34 \\
\hline Cal F & 7.30 & 7.24 & 55.65 & 3.46 & 6.76 & 4.76 & 9.16 & 10.76 & 14.96 \\
\hline $\mathrm{SE}(\mathrm{m} \pm)$ & 0.90 & 0.92 & 1.49 & 0.33 & 0.38 & 0.23 & 0.46 & 0.82 & 3.28 \\
\hline $\mathrm{SE}(\mathrm{d} \pm)$ & 1.28 & 1.30 & 2.11 & 0.47 & 0.53 & 0.32 & 0.65 & 1.16 & 4.64 \\
\hline$C D$ & 2.60 & 2.64 & 4.31 & 0.96 & 1.09 & 0.66 & 1.32 & 2.37 & 9.48 \\
\hline $\mathrm{CV}$ & 4.10 & 3.89 & 6.07 & 16.64 & 13.01 & 15.18 & 6.14 & 14.38 & 12.78 \\
\hline
\end{tabular}

* Significant at $P \leq 0.05 ;$ Tab value of $F$ at $17,34 \mathrm{df}=1.93$

Table 5 Performance of the parents and 16 Co-4 gene-positive $\mathrm{BC}_{2} \mathrm{~F}_{4}$ progenies for 9 quantitative agro-horticultural traits

Table 6 Promising Co-4 gene-positive backcross progenies identified for 9 agro horticultural traits 


\begin{tabular}{|c|c|c|c|c|c|c|c|c|c|}
\hline $\begin{array}{l}\text { Co-4 gene- } \\
\text { positive } \\
\mathrm{BC}_{2} \mathrm{~F}_{4} \text { proginies }\end{array}$ & $\begin{array}{l}\text { Days to } \\
\text { flowering } \\
\text { Initiation }\end{array}$ & $\begin{array}{l}\text { Days to } \\
50 \text { per } \\
\text { cent } \\
\text { flowering }\end{array}$ & $\begin{array}{l}\text { Plant } \\
\text { height at } \\
50 \text { per } \\
\text { cent } \\
\text { flowering } \\
\text { (cm) }\end{array}$ & $\begin{array}{l}\text { Branches } \\
\text { /plant }\end{array}$ & $\begin{array}{l}\text { Pod bearing } \\
\text { nodes/plant }\end{array}$ & $\begin{array}{l}\text { Pods/ } \\
\text { Node }\end{array}$ & $\begin{array}{l}\text { Pod } \\
\text { length } \\
\text { (cm) }\end{array}$ & Pods/plant & $\begin{array}{l}\text { Green } \\
\text { pod } \\
\text { yield/ } \\
\text { plant(g) }\end{array}$ \\
\hline AKTO 4 & 42.33 & 44.67 & 46.67 & 3.50 & 6.17 & 2.33 & 13.17 & 10.50 & 45.83 \\
\hline AKTO 5 & 37.50 & 39.00 & 35.17 & 3.00 & 5.33 & 2.67 & 13.60 & 13.67 & 57.50 \\
\hline AKTO 7 & 40.83 & 43.00 & 53.00 & 3.83 & 4.33 & 3.50 & 13.22 & 12.33 & 65.00 \\
\hline AKTO 8 & 37.00 & 39.67 & 41.83 & 3.67 & 4.50 & 3.50 & 11.65 & 12.17 & 53.33 \\
\hline AKTO 10 & 34.67 & 37.83 & 41.83 & 4.00 & 4.33 & 2.33 & 12.97 & 5.33 & 28.33 \\
\hline AKTO 19 & 35.67 & 40.33 & 41.33 & 3.33 & 4.17 & 2.67 & 13.85 & 8.33 & 44.17 \\
\hline AKTO 24 & 36.33 & 38.00 & 42.33 & 3.50 & 4.17 & 2.83 & 11.88 & 8.67 & 35.83 \\
\hline AKTO 28 & 36.67 & 39.33 & 40.50 & 2.50 & 4.33 & 2.17 & 13.43 & 7.33 & 31.67 \\
\hline AKTO 29 & 38.83 & 40.67 & 38.67 & 3.67 & 5.33 & 2.50 & 13.08 & 10.17 & 50.00 \\
\hline AKTO 33 & 39.67 & 43.33 & 40.67 & 3.33 & 4.67 & 2.17 & 13.20 & 11.00 & 37.50 \\
\hline AKTO 36 & 42.17 & 45.17 & 33.67 & 4.00 & 4.67 & 2.17 & 11.23 & 6.17 & 33.33 \\
\hline AKTO 40 & 38.83 & 41.50 & 36.33 & 4.00 & 5.83 & 2.67 & 12.98 & 12.33 & 53.33 \\
\hline AKTO 42 & 35.50 & 38.00 & 31.00 & 3.17 & 3.83 & 2.67 & 11.37 & 7.67 & 31.67 \\
\hline AKTO 43 & 37.00 & 39.67 & 50.50 & 3.00 & 8.00 & 3.33 & 14.20 & 14.67 & 61.67 \\
\hline AKTO 45 & 39.00 & 41.17 & 30.83 & 3.83 & 5.00 & 2.67 & 13.33 & 7.83 & 36.67 \\
\hline AKTO 46 & 38.50 & 40.67 & 37.17 & 3.33 & 5.67 & 2.50 & 13.98 & 7.33 & 32.50 \\
\hline Arka Komal & 34.83 & 37.00 & 45.83 & 4.50 & 4.83 & 2.50 & 15.83 & 10.17 & 67.67 \\
\hline TO & 41.50 & 44.00 & 80.17 & 1.83 & 5.33 & 1.50 & 9.53 & 12.50 & 35.00 \\
\hline$S E(m \pm)$ & 0.90 & 0.92 & 1.49 & 0.33 & 0.38 & 0.23 & 0.46 & 0.82 & 3.28 \\
\hline$C D$ & 2.60 & 2.64 & 4.31 & 0.96 & 1.09 & 0.66 & 1.32 & 2.37 & 9.48 \\
\hline
\end{tabular}




\begin{tabular}{|c|c|c|c|}
\hline Trait & $\begin{array}{l}\text { Better } \\
\text { parent } \\
\text { (BP) }\end{array}$ & $\begin{array}{l}\text { Progenies at par with elite } \\
\text { parent } \\
\text { (Four Best) }\end{array}$ & $\begin{array}{l}\text { Progenies superior than elite } \\
\text { parent } \\
\text { (All) }\end{array}$ \\
\hline \multirow[t]{2}{*}{ Days to flowering initiation } & Arka Komal & AKTO 10, AKTO 19 & - \\
\hline & & AKTO 24, АKTO 42 & \\
\hline \multirow[t]{2}{*}{ Days to 50 per cent flowering } & Arka Komal & AKTO 5, AKTO 10 & - \\
\hline & & AKTO 24, AKTO 42 & \\
\hline \multirow{2}{*}{$\begin{array}{l}\text { Plant height at } 50 \text { per cent flowering } \\
(\mathrm{cm})\end{array}$} & Arka Komal & AKTO 4, AKTO 8 & - \\
\hline & & AKTO 10, AKTO 24 & \\
\hline \multirow[t]{2}{*}{ Branches/plant } & Arka Komal & AKTO 7, AKTO 10 & - \\
\hline & & AKTO 36, АKTO 40 & \\
\hline \multirow[t]{2}{*}{ Pod bearing nodes/ plant } & TO & AKTO 5, AKTO 29 & AKTO 4, AKTO 43 \\
\hline & & AKTO 40, АKTO 46 & \\
\hline \multirow[t]{2}{*}{ Pods/node } & Arka Komal & AKTO 5, AKTO 19 & AKTO 7, AKTO 8 \\
\hline & & AKTO 24, АKTO 43 & AKTO 43 \\
\hline Pod length(cm) & Arka Komal & - & - \\
\hline \multirow[t]{2}{*}{ Pods/plant } & TO & AKTO 7, AKTO 8 & AKTO 5, AKTO 43 \\
\hline & & AKTO 33, AKTO 40 & \\
\hline Green pod yield/ plant (g) & Arka Komal & AKTO 7, AKTO 43 & - \\
\hline
\end{tabular}

\section{Figures}

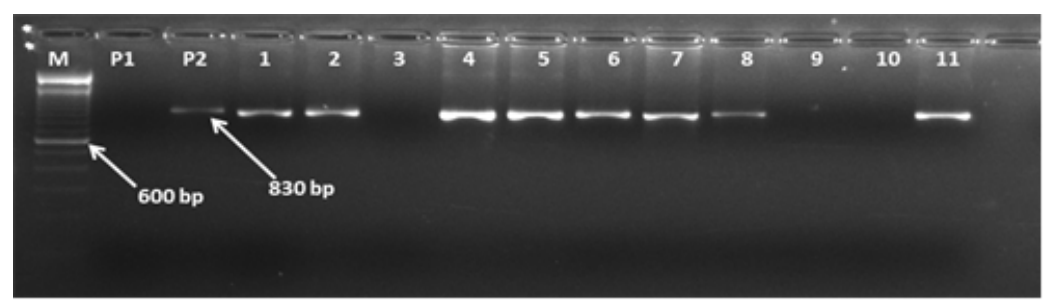

\section{Figure 1}

Agarose gel showing presence/absence of amplification products ( $830 \mathrm{bp}$ bands) of SCAR marker, SY20 in the parents and $\mathrm{F}_{1}$ progenies (The first lane from left is molecular weight marker (100 bp ladder), P1= susceptible parent (Arka Komal), P2= resistant parent (TO), 1-11 are $\mathrm{F}_{1}$ (Arka Komal × TO) hybrid pod progenies)

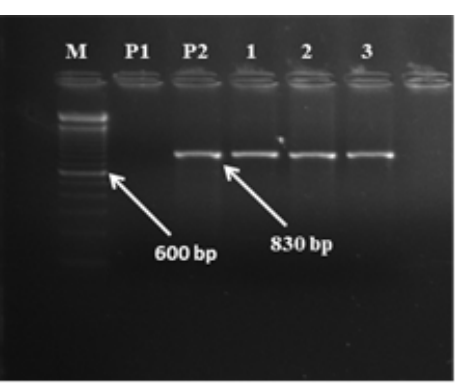




\section{Figure 2}

Agarose gel showing presence/absence of amplification products ( $830 \mathrm{bp}$ bands) of SCAR marker, $S Y 20$ in the parents and BC $\mathrm{F}_{1}$ progenies (The first lane from left is molecular weight marker (100 bp ladder), $P 1=$ susceptible parent (Arka Komal), P2= resistant parent (TO), 1-3 are $B C_{1} F_{1}\left\{\right.$ Arka Komal $\times F_{1}$ (Arka Komal $\times$ TO) $\}$ backcross pod progenies)

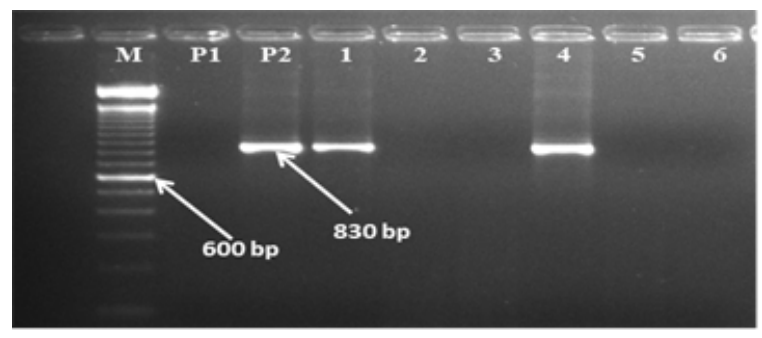

\section{Figure 3}

Agarose gel showing presence/absence of amplification products ( $830 \mathrm{bp}$ bands) of SCAR marker, SY2O in the parents and BC $\mathrm{F}_{1}$ progenies (The first lane from left is molecular weight marker (100 bp ladder), $P 1=$ susceptible parent (Arka Komal), P2= resistant parent (TO), 1-6 are $B C_{2} F_{1}\left[\right.$ Arka Komal $\times B C_{1} F_{1}\left\{\right.$ Arka Komal $\times F_{1}$ (Arka Komal $\times$ TU)\}] backcross pod progenies)

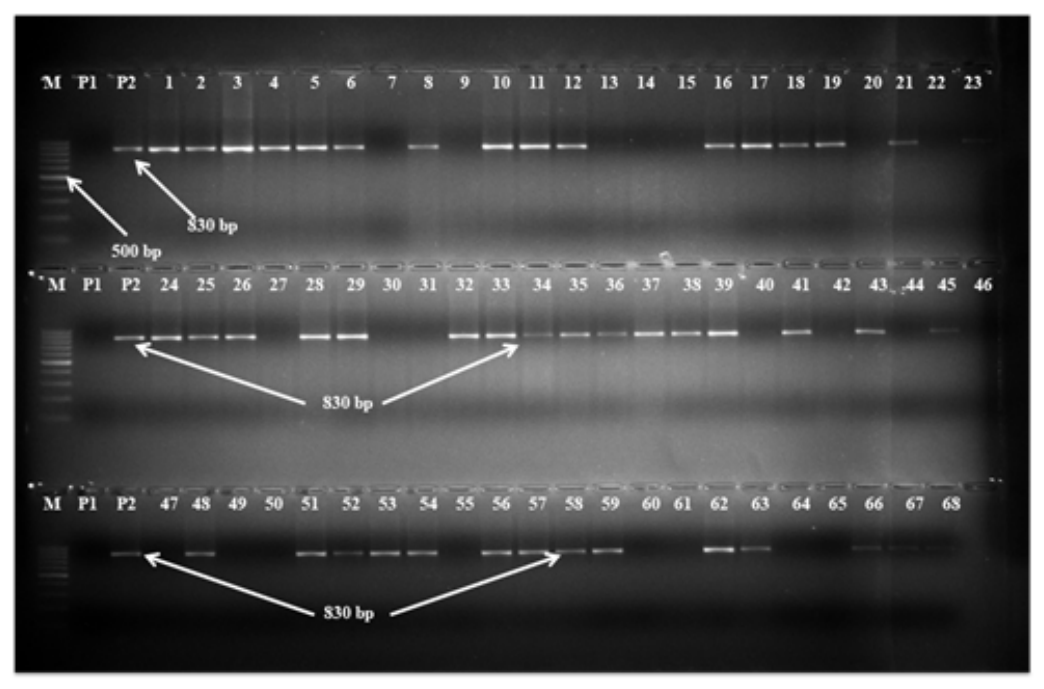

\section{Figure 4}

Agarose gel showing presence/absence of amplification products ( $830 \mathrm{bp}$ bands) of SCAR marker, $S Y 20$ in the parents and $\mathrm{BC}_{2} \mathrm{~F}_{2}$ plants (The first lane from left is molecular weight marker (100 bp ladder), $P 1=$ susceptible parent (Arka Komal), P2= resistant parent (TO) and 1-68 are $B C_{2} F_{2}$ hybrid pod progenies) 


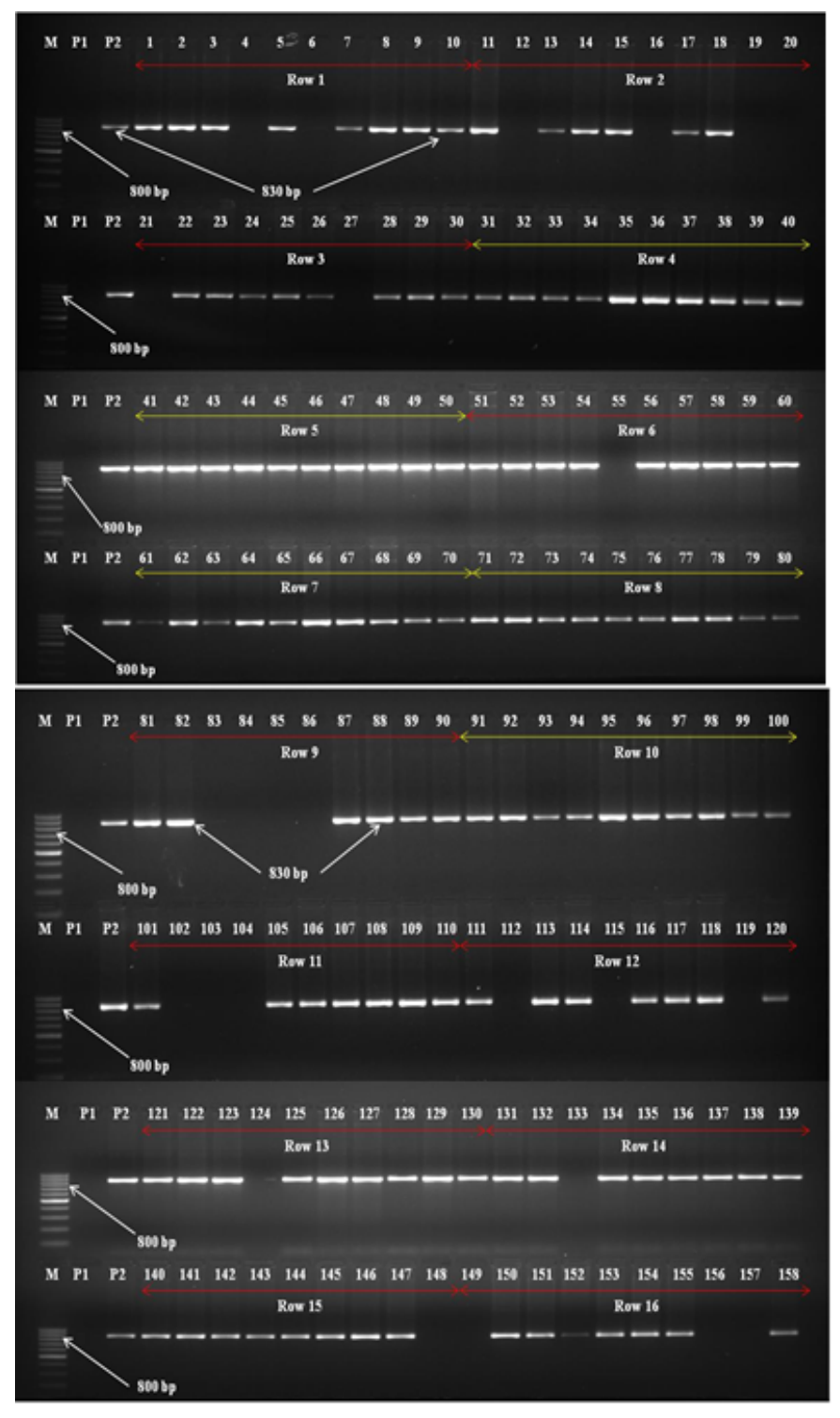

\section{Figure 5}

Agarose gel showing presence/absence of amplification products (830 bp bands) of SCAR marker, SY20 in the parents and 1-158 $\mathrm{BC}_{2} \mathrm{~F}_{3}$ plants (The first lane from left is molecular weight marker (100 bp ladder), $P 1=$ susceptible parent (Arka Komal), $P 2=$ resistant parent (TO) and 1-158 are $B C_{2} F_{3}$ plants of Co-4 gene containing rows. The rows presented in red arrow are heterozygous and rows presented in yellow arrow are homozygous lines as all the plants in the row were gene-positive (showed lack of segregation)). 


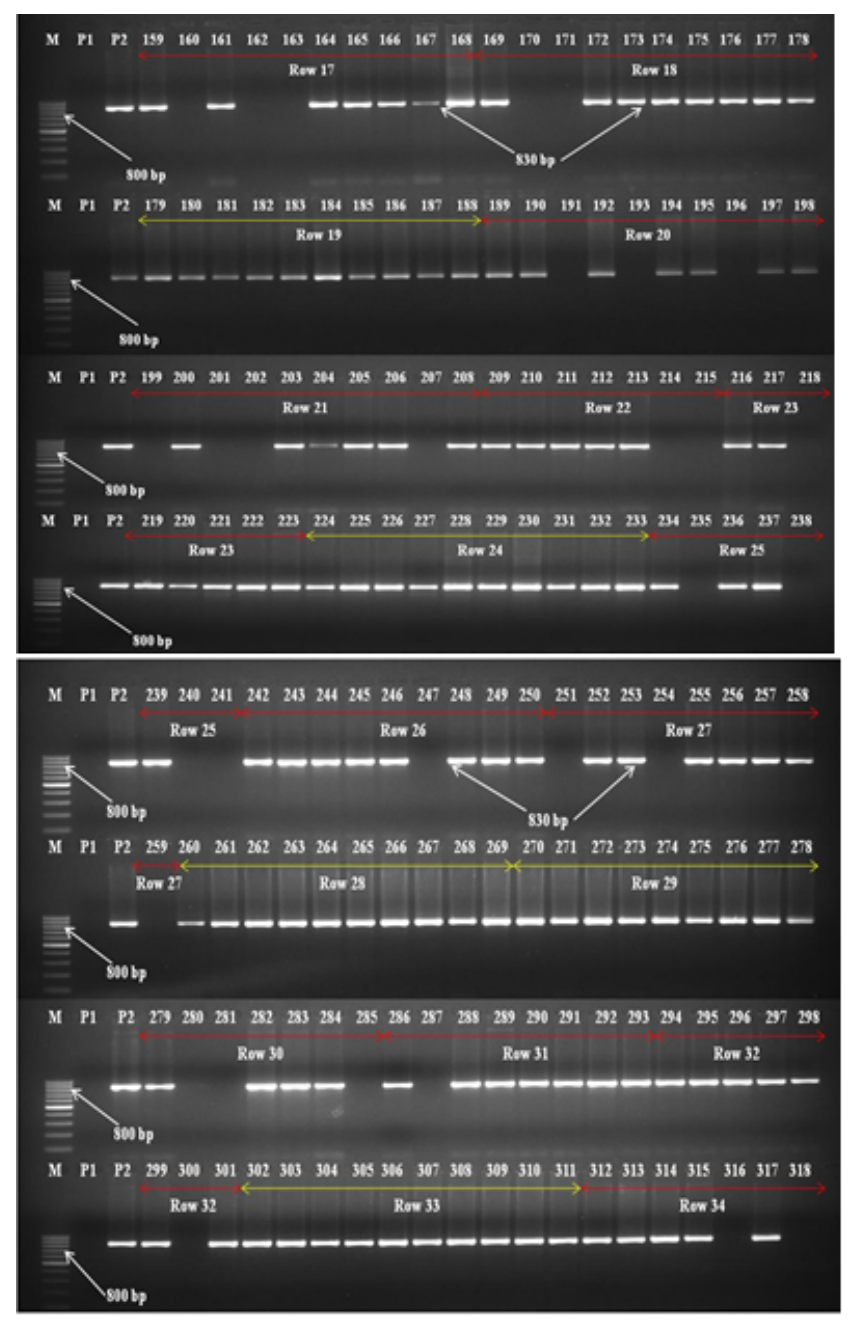

\section{Figure 6}

Agarose gel showing presence/absence of amplification products (830 bp bands) of SCAR marker, SY20 in the parents and 159-318 $\mathrm{BC}_{2} \mathrm{~F}_{3}$ plants (The first lane from left is molecular weight marker (100 bp ladder), $\mathrm{P} 1=$ susceptible parent (Arka Komal), $P 2=$ resistant parent (TO) and 159-318 are $\mathrm{BC}_{2} \mathrm{~F}_{3}$ plants of Co-4 gene containing rows. The rows presented in red arrow are heterozygous and rows presented in yellow arrow are homozygous lines as all the plants in the row were gene-positive (showed lack of segregation)). 


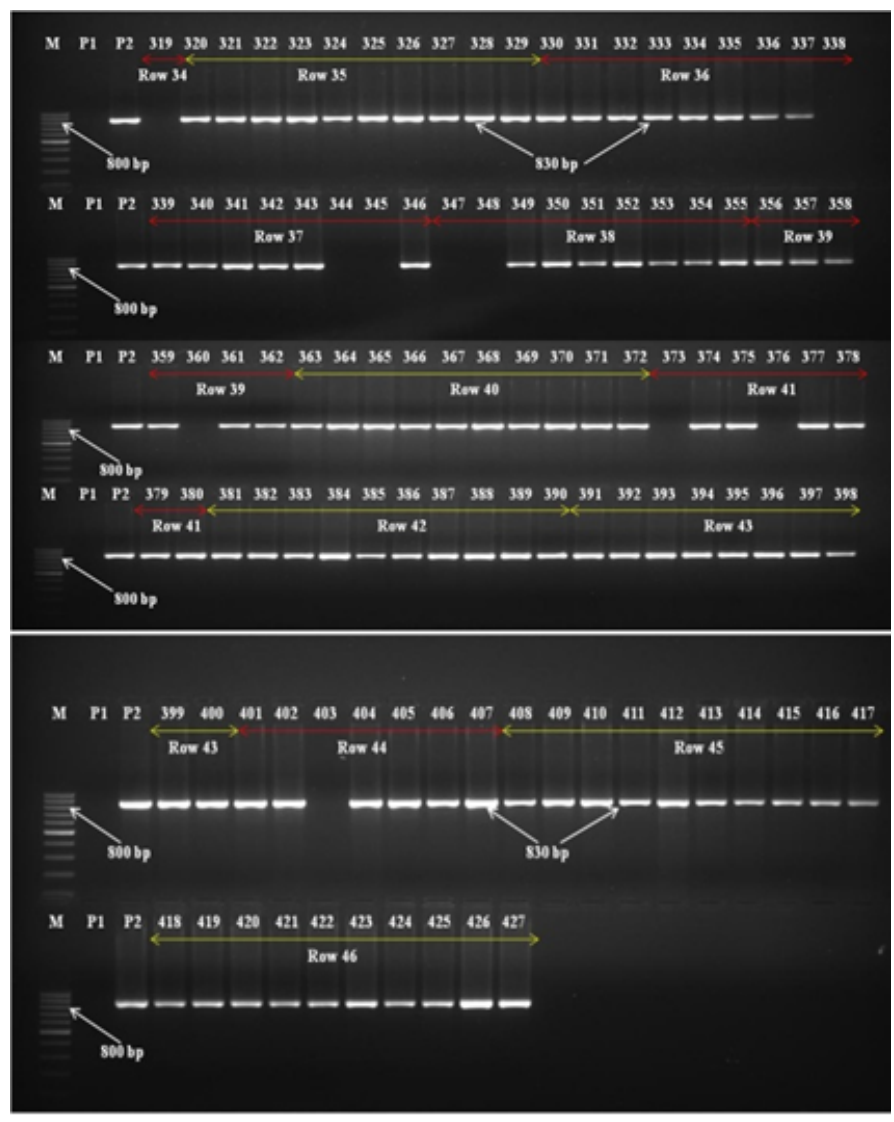

\section{Figure 7}

Agarose gel showing presence/absence of amplification products ( $830 \mathrm{bp}$ bands) of SCAR marker, SY20 in the parents and 319-427 $\mathrm{BC}_{2} \mathrm{~F}_{3}$ plants (The first lane from left is molecular weight marker (100 bp ladder), $P 1=$ susceptible parent (Arka Komal), P2 = resistant parent (TO) and 319-427 are $B_{2} F_{3}$ plants of Co-4 gene containing rows. The rows presented in red arrow are heterozygous and rows presented in yellow arrow are homozygous lines as all the plants in the row were gene-positive (showed lack of segregation)).
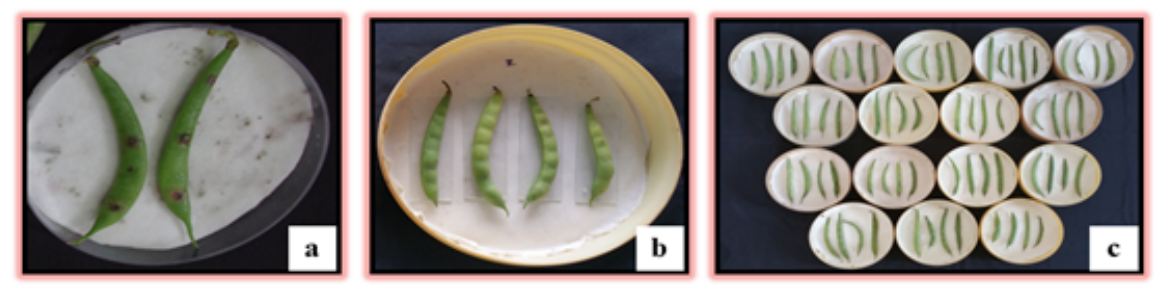

\section{Figure 8}

Screening of $\mathrm{BC}_{2} \mathrm{~F}_{3}$ progenies and parents against pathogen, Colletotrichum lindemuthianum race- 3 using detached pod method a) Disease symptoms on susceptible parent 'Arka Komal' ; b) Healthy pods of resistant parent 'TO'; c) Row-1: AKTO- 4, 5, 7, 8, 10; Row-2: AKTO- 19, 24, 28, 29; Row-3: AKTO- 33, 36, 40, 42; Row-4: AKTO- 43, 45, 46 


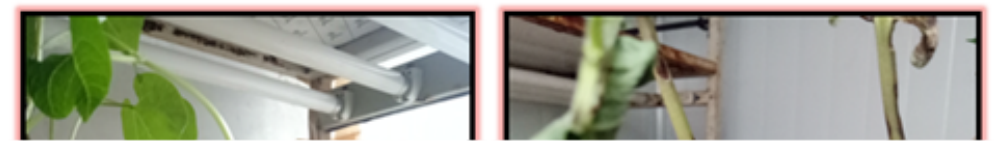

\section{Figure 9}

Screening of parents against pathogen, Colletotrichum lindemuthianum race-3 by germinated seed dip method a) Healthy leaves and stems of resistant parent 'TO'; b) Disease symptoms on susceptible parent 'Arka Komal'; c \&d) Healthy leaves and stems of 16 homozygous lines for Co-4 gene 